\title{
Iron as the concert master in the pathogenic orchestra playing in sporadic Parkinson's disease
}

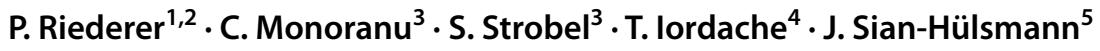

Received: 13 July 2021 / Accepted: 29 August 2021 / Published online: 12 October 2021

(c) The Author(s) 2021

\begin{abstract}
About 60 years ago, the discovery of a deficiency of dopamine in the nigro-striatal system led to a variety of symptomatic therapeutic strategies to supplement dopamine and to substantially improve the quality of life of patients with Parkinson's disease (PD). Since these seminal developments, neuropathological, neurochemical, molecular biological and genetic discoveries contributed to elucidate the pathology of PD. Oxidative stress, the consequences of reactive oxidative species, reduced antioxidative capacity including loss of glutathione, excitotoxicity, mitochondrial dysfunction, proteasomal dysfunction, apoptosis, lysosomal dysfunction, autophagy, suggested to be causal for a-synuclein fibril formation and aggregation and contributing to neuroinflammation and neural cell death underlying this devastating disorder. However, there are no final conclusions about the triggered pathological mechanism(s) and the follow-up of pathological dysfunctions. Nevertheless, it is a fact, that iron, a major component of oxidative reactions, as well as neuromelanin, the major intraneuronal chelator of iron, undergo an age-dependent increase. And ageing is a major risk factor for PD. Iron is significantly increased in the substantia nigra pars compacta (SNpc) of PD. Reasons for this finding include disturbances in iron-related import and export mechanisms across the blood-brain barrier (BBB), localized opening of the BBB at the nigro-striatal tract including brain vessel pathology. Whether this pathology is of primary or secondary importance is not known. We assume that there is a better fit to the top-down hypotheses and pathogens entering the brain via the olfactory system, then to the bottom-up (gutbrain) hypothesis of PD pathology. Triggers for the bottom-up, the dual-hit and the top-down pathologies include chemicals, viruses and bacteria. If so, hepcidin, a regulator of iron absorption and its distribution into tissues, is suggested to play a major role in the pathogenesis of iron dyshomeostasis and risk for initiating and progressing a-synuclein pathology. The role of glial components to the pathology of PD is still unknown. However, the dramatic loss of glutathione (GSH), which is mainly synthesized in glia, suggests dysfunction of this process, or GSH uptake into neurons. Loss of GSH and increase in SNpc iron concentration have been suggested to be early, may be even pre-symptomatic processes in the pathology of $\mathrm{PD}$, despite the fact that they are progression factors. The role of glial ferritin isoforms has not been studied so far in detail in human post-mortem brain tissue and a close insight into their role in PD is called upon. In conclusion, "iron" is a major player in the pathology of PD. Selective chelation of excess iron at the site of the substantia nigra, where a dysfunction of the BBB is suggested, with peripherally acting iron chelators is suggested to contribute to the portfolio and therapeutic armamentarium of anti-Parkinson medications.
\end{abstract}

Keywords Iron in Parkinsonism · Parkinson's disease · Iron transporter · Neuromelanin · Iron pathology ·

Neuroinflammation · Iron model · Ferroptosis · a-Synuclein and iron · Virus-iron interaction · COVID-19 · Hepcidin ·

SARS-CoV-2

This review is dedicated to the Doyen of worldwide neuropathology, Kurt Jellinger, on the occasion of his 90th birthday. Peter Riederer thankfully acknowledges the longlasting fruitful scientific cooperation with Kurt and his prominent interest in elucidating the mysteries of iron pathology in Parkinson's disease. Ad multos annos, Kurt!

Extended author information available on the last page of the article

\section{Introduction}

Evolution of the human being was and will never be possible without the action of a variety of metals, like sodium, potassium, calcium, zinc, copper, manganese, iron, aluminium, nickel and others. However, understanding their mode of action (MoA) was possible only by the development of 


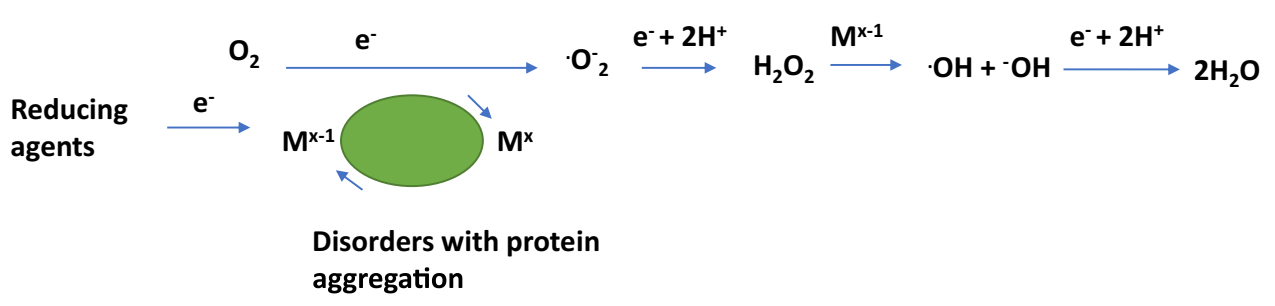

Fig. 1 Generation of oxidative species by redox-active metals. $\mathrm{M}^{\mathrm{x}-1}$ iron ions (eventually copper ions) in the reduced state, $\mathrm{M}^{\mathrm{x}}$ iron/copper ions, $\mathrm{O}_{2}$ molecular oxygen, $\mathrm{O}_{2}^{-}$superoxide radical, $\mathrm{H}_{2} \mathrm{O}_{2}$ hydrogen peroxide, $\mathrm{OH}$ hydroxyl radical, ${ }^{-} \mathrm{OH}$ hydroxyl ion

highly sophisticated armamentaria of methodologies over the past decades. These methods allowed to get insights into the biological mechanisms of metal ions interaction with peptides/proteins, enzymes, nucleotides etc.. Transport, metabolism, metal deficit and accumulation, respectively, and metal toxicity became important research fields (Sigel et al. 2006) (Fig. 1).

In this review, we focus on "iron" and its role in the pathology of Parkinson's disease (PD). The brain utilizes metal ions for many metabolic purposes. Compared with other tissues, the brain shows the highest metabolic rate and need for aerobic metabolism. Uptake of iron is not as ease, because the blood-brain barrier (BBB) is a natural barrier for iron-uptake. Therefore, iron is taken up using transport proteins, like transferrin. Transferrin binds iron and this complex after endocytosis releases iron intracellularly through divalent metal transporter 1. Iron exit from brain is controlled by ferroportin, hepcidin and ferroxidases (Vela 2018; Zecca et al. 2004b; Gerlach et al. 2021).

This condition is a vulnerable one for redox-active metals, like iron and copper. Indeed, reactive oxygen species (ROS) play a dominant role in the pathology of neurodegenerative disorders, like Parkinson's disease (PD) and Alzheimer disease (AD). A majority of radicals and ROS arise from redox reactions of metals (Berg et al. 2004). Metals, like iron and copper in their reduced state reduce oxygen $\left(\mathrm{O}_{2}\right)$ to superoxide $\mathrm{O}_{2}^{-}$which is dismutated to hydrogen peroxide $\left(\mathrm{H}_{2} \mathrm{O}_{2}\right) . \mathrm{H}_{2} \mathrm{O}_{2}$ crosses membranes and can be scavenged by glutathione peroxidase, catalase, etc. If not scavenged, $\mathrm{H}_{2} \mathrm{O}_{2}$ may react with reduced metals to generate hydroxyl radicals $(\cdot \mathrm{OH})$. As $\mathrm{OH}$ is an extremely reactive radical species, it reacts easily with lipids, proteins to form, e.g. protein aggregation products and even RNA and DNA adducts (Sigel et al. 2006). Indeed iron-associated disorders can be divided as (1) genetic disorders, like Friedreich's ataxia (frataxin), neurodegenerations with brain iron accumulation (NBIA), pantothenate kinase 2-associated neurodegenerations, neuroferritinopathy (mutation of ferritin light chain) and aceruloplasminemia (together with copper; mutations in the ceruloplasmin gene), hemochromatosis (mutations in the HFE gene) and (2) disorders with protein aggregation, like PD (and eventually associated with copper pathology) (Schneider 2016; Gerlach et al. 2006). However, the notion is important, that iron accumulation can be detected in many other neurodegenerative disorders, like AD, Huntington's chorea, multiple system atrophy (MSA), progressive supranuclear palsy (PSP). In all these disorders iron accumulation is specifically located in brain regions associated with the key pathology of the disorder. For example, in AD increased iron concentration has been found in cortical brain areas (Ward and Crichton 2019; Seitelberger 1964), while there is iron pathology in PD detected in the substantia nigra pars compacta (SNpc); in MSA not only there is an accumulation in the SN but also in the striatum and the same holds true for PSP. From such data, it is not farfetched to assume that iron pathology may be a secondary mechanism facilitating neurodegeneration rather than a primary causal trigger. To support this assumption, it has been demonstrated, that iron shows an age-dependent increase and distribution in the various brain areas, as already shown by Spatz (1922), Müller (1922), Hallgren and Sourander (1958), Schmidt (1940), Volkl and Ule (1972), and Ule et al. (1974).

Early measurements of total iron in qualitative histological iron stainings (Schmidt 1940; Müller 1922; Spatz 1922) and in quantitative analyses have been reported in healthy individuals in many brain regions with the highest concentrations in globus pallidus, SN, putamen, caudate nucleus and red nucleus (Hallgren and Sourander 1958; Ule et al. 1974; Volkl and Ule 1972; Stern et al. 1967). This is of interest, because there are no regional differences in the concentrations of zinc, calcium and magnesium (Ule et al. 1974).

Of interest is the notion, that non-heme iron can be detected especially in mitochondria and microsomes (46\% on average). $14 \%$ were found in nuclei and the remaining $40 \%$ in the soluble fraction (Hallgren and Sourander 1958). Ule et al. (1974) assumed that iron, copper and zinc are bound to functional active macromolecules, like coenzymes, structural proteins or deposited pigments, although not much detailed, Spatz already mentioned in 1922 (on page 312) (Spatz 1922), that there is iron bound to pigment in the SN. 


\section{Iron in Parkinson's disease}

Lhermitte et al. (1924) have described abnormal deposits of iron in globus pallidus but not in the $\mathrm{SN}$ of a patients with akinetic-rigid PD. Using different technologies, like X-ray fluorescent spectroscopy (Earle 1968), magnetic resonance imaging (Rossi et al. 2013; Lee and Lee 2019; Drayer et al. 1986), inductively coupled plasma spectroscopy (Dexter et al. 1987), X-ray microanalysis (Hirsch et al. 1991; Kienzl et al. 1995; Jellinger et al. 1992), spectrophotometry (Sofic et al. 1988), T2*-, R2*- susceptibility weighting imaging (Wang et al. 2016; Graham et al. 2000), transcranial sonography (Becker et al. 1995; Berg et al. 2005), quantitative susceptibility mapping (Pyatigorskaya et al. 2020), FDRI -method, iron relaxometry techniques, PRISME MRI and other imaging methods an increase of total iron in the SNpc could be established, as summarized by Chen et al. (2019), Genoud et al. (2020), Gerlach et al. (1994, 2006, 2021) and Feraco et al. (2021). In patients with von Economo encephalitis epidemica at late stages of the disease an accumulation of iron in the SN has been mentioned by Seitelberger (1964). In contrast to previous observers, Rutledge et al. (1987) did not find that MR signal correlated between Perls' stain and the signal void exists everywhere. This early finding has been noted also by other researchers and has been discussed recently in more detail. Haacke et al. (2005) examined the response of the magnetic resonance visible iron in tissue that produces signal changes in both magnitude and phase imaging and assumed that these images seem to correlate with brain iron content, perhaps ferritin specifically.

The mismatch of T2*-weighted MRI and Perl stains has been noted also by Blazejewska et al. (2013) in an imaging study of 2 subjects with unknown neurological condition (67 resp. 46 years old) and one patient diagnosed with PD (75 years old). Brains were fixed in $10 \%$ formalin (see our comments below). Although the data from this study are only preliminary (number of individuals, no healthy controls for comparison, age differences, $10 \%$ formalin for fixation), they relate the problem of the mismatch to a higher concentration of iron (II) in PD brain due to the fixation process and/or increased oxidative stress, while Perl stains only iron (III). Certainly measurements of the proportion of divalent/ trivalent iron (Sofic et al. 1988; Galazka-Friedman et al. 1996) are a challenge due to methodological uncertainties (Friedman and Galazka-Friedman 2012; Hare et al. 2012).

The review of Haacke et al. (2005) seems to be a good basis for the development of image analyses to improve the detection of iron with $\mathrm{T} 1$ and $\mathrm{T} 2$ techniques. In fact, Haacke's group (Mittal et al. 2009) described susceptibility weighted imaging (SWI), which is 3-6 times more sensitive than conventional $\mathrm{T} 2 *$ weighted gradient echo sequences and gave example for clinical applications. The review of Feraco et al. (2021) describes the development of iron imaging techniques with details for nigrosome imaging, neuromelanin-sensitive sequences, iron-sensitive sequences and advanced diffusion weighted imaging techniques, which all afford new insights into the non-invasive study of the SNpc.

An interesting study using $\mathrm{T} 1$ and $\mathrm{T} 2 *$ mapping in ironoverload-related heart failure may give an answer for preferring $\mathrm{T} 1$ or $\mathrm{T} 2 *$ mapping when measuring iron concentrations (Torlasco et al. 2018). These authors concluded their studies as follows: $\mathrm{T} 1$ and $\mathrm{T} 2 *$ are concordant as long as the slopes for $\mathrm{T} 2 *$ are high. Nevertheless, while the sensitivity of conventional MRI sequences, i.e. T2 or T1 weighted, has been considered as poor for the detection of early PD (see Feraco et al. (2021)) these authors state, that quantitative susceptibility mapping and $\mathrm{R} 2 *$ may be effective tools for early detection as well as for the dynamic progression of PD.

For the detection of free (labile) iron, it should be critically noted that there are several caveats to be considered (Hare et al. 2012; Friedman and Galazka-Friedman 2012), like a metal transfer due to sampling, fixation and storage of post-mortem brain tissue, impact of analytical sensitivity (Hare et al. 2012), hemispheric asymmetry with a higher concentration of iron in the left hemisphere (Xu et al. 2008) and most importantly the measurement of changes in total iron and the labile iron pool (Hare et al. 2012). Here we focus on some methodological problems which have direct influence for the interpretation of findings related to free (labile) vs. total iron and their correlation to the pathology of PD: (1) as total iron is increased, does it mean, that free (labile) iron is increased too and is the relation of free to bound (ferritin, neuromelanin (NM)) iron an aspect to be considered important for the pathology of PD? and (2) is the increase of iron correlated to the staging of $\mathrm{PD}$ progression and is there specificity of increased SN iron in PD?

$A d$ (1) Free vs. bound iron: although an increase of free (labile) iron has been published by Wypijewska et al. (2010), there are no other publications supporting these data. This fact is not surprising, because quantitative detection of free cytoplasmic iron in formalin-fixed tissues is not possible due to the destruction of tissue membrane substructures. If not formalin-fixed, fresh tissue can be used or fresh-frozen tissue. In the latter case, however, freezing protocols would have been to be used extremely carefully avoiding shockfreezing protocols and using instead slow/mild temperature reducing protocols (Hare et al. 2012). To detect free iron in fresh tissue or in frozen SN (frozen down using membrane protecting protocols) such tissue would have been to be merged using extremely tight methodology, e.g. squashing of tissue, but not using cutting technologies under cooling conditions. All these analytical procedures are extremely tricky and would have been followed by membrane filtration using ultra capsules to separate free from bound iron with the time-dependent possibility that the equilibrium of free and bound iron is changed. To avoid such complicated 
methodology tissue in toto is placed into fluid; then free tissue iron is assumed to diffuse into such fluid with the possibility to be easily measured. However, iron equilibrium of free and bound iron might be changed as this is a time consuming strategy and longer time offers a greater possibility for changing this equilibrium in favour of free iron concentration.

$\operatorname{Ad}(2)$ iron and staging of PD

Although, and mentioned above, there is overwhelming evidence that iron is increased in the $\mathrm{SN}$ of sporadic $\mathrm{PD}$, nevertheless, there are a few reports from post-mortem analyses showing that iron is not changed when compared to controls (Gałazka-Friedman et al. 1996; Friedman et al. 2009; Uitti et al. 1989; Ryvlin et al. 1995). Reasons for these discrepancies are several fold and include (1) fixing protocols of post-mortem tissue, e.g. has the whole brain or just one of the hemispheres been fixed in formalin? If so, which one? Were brain slices or special regions fixed as well? Furthermore, knowledge about the concentration of formalin, number of repeated exchanges $(\mathrm{N})$ of formalin, times between these repeated fluid exchanges, duration of formalin fixation, use of phosphate-buffered formalin or formalin fixation without buffered fluid, washout phases of formalin (N) with water resp. considering also the composition of this fluid would be of interest. This is, because and as mentioned already by Spatz et al. (1922), who described the loss of iron in long-term treated brains with formalin. In addition, such information would give evidence for the redox potential of fluids integrated into the fixation protocol. Our own experience shows the phosphate-buffered formalin is superior to pure formalin for histological/immunohistological research strategies (Heinsen, pers.comm.); (2) length of tissue storage and storage conditions, e.g. storage in formalin or as paraffin-embedded blocks (see also Hare et al. 2012; Friedman and Galazka-Friedman 2012; Blazejewska et al. 2013). Furthermore, time between death and brain autopsy as well as between brain autopsy and fixation protocol, temperature condition, dissection uncertainties of the substructure of the SN, e.g. SN pars compacta. SN pars reticulata (Sofic et al. 1991) or SN to red nucleus, have been suggested to influence measurements of iron in post-mortem brain tissue (Friedman and Galazka-Friedman 2012; Hare et al. 2012; Blazejewska et al. 2015). In addition, it would be of great importance to learn about the origin of post-mortem tissue. For example, have post-mortem brain tissue of controls and PD collected at the same neuropathological institute or have they been collected at different neuropathologies? (Earle 1968; Schrag et al. 2010; Gellein et al. 2008).

While such details are mostly not reported in respective publications, the notion may be of interest namely that Spatz (1922) reported the disappearance of iron staining in long-term formalin fixed tissue. Another aspect is the fact that there are different progression rates of PD, which may indeed influence iron-induced pathology. Indeed, no increase of iron concentration has been found in incidental Lewy body disease (ILBD) (Dexter et al. 1991) and in PD with milder SN pathology (Bartzokis et al. 1999; Riederer et al. 1989)). Bartzokis et al. (1999) studied iron content in the extrapyramidal system in early- and late-onset PD by MRI-technique. This group showed that there were significant increases in early-onset PD in field-dependent R2 increases (FDRI) in the SN, putamen and globus pallidus, while later onset $\mathrm{PD}$ subjects had significantly decreased FDRI in the SN pars reticulata. These authors concluded that the increase of iron in the SN of PD as measured post-mortem is in line with the decreased FDRI measure in late-onset patients detected in their study (Bartzokis et al. 1999). Iron accumulation was not significant in different regions of interest in newly diagnosed patients with PD after adjustment for age (Dashtipour et al. 2015). However, these authors calculated an average phase value from the left and right hemispheral side, thus not considering different pathological states in the regions of interest, like the SN. Indeed, post-mortem findings showing an increase of SN iron and performed in tissue from advanced $\mathrm{PD}$ are overwhelming as mentioned above. However, a conclusion, that increase of total iron is correlated to advanced $\mathrm{PD}$ stages is questionable considering $\mathrm{SN}$-iron-related imaging, which shows increased iron-related alterations in eventually pre-symptomatic individuals as published by Becker et al. (1995) and Berg et al. (1999). However, later clinical studies showed, that hyperechogenicity detected by transcranial ultrasound imaging is a highly increased risk for PD in elderly individuals (Berg et al. 2011) only, while other studies demonstrated SN hyperechogenicity also in other disease entities (Berg 2011). With MRI (3 Tesla magnet) using a multiple gradient echo sequence designed for rapid singlescan mapping of the proton transverse relaxation rate $\mathrm{R} 2 *$ Martin et al. (2008) demonstrated increased iron content in early PD. Hyperechogenicity of the SN has been shown in the 6-hydroxydopamine model of PD to depend on iron accumulation and microglia activation (Zhu et al. 2017). Such studies are important in order to get insights into the role of iron as a trigger of PD pathology and/or a deleterious disease progression factor. As the $\mathrm{SN}$ is the predominant brain region showing increased iron deposits in PD, the question raises as to the reasons of such localized pathology. Animal studies give evidence for a disturbed BBB in 6-hydroxydopamine lesioned animals with increase of SN iron and albumin (as indicator of a leaky BBB) (Oestreicher et al. 1994; Arendash et al. 1993). Alternatively, it has been suggested, there might be disturbances in the mechanisms of iron-uptake, iron-transport and iron-storage. 


\section{Iron-induced pathology in the SN pars compacta of PD}

Transferrin has been shown to be decreased in the SN of PD by 35\% (Ayton et al. 2016). Such data agree with those by Morris et al. (1994), but is correlated with the loss of nigral neurons (Morris et al. 1994). Loeffler et al. (1995) concluded from their studies, that the transferrin/iron ratio, a measure of iron mobilization capacity, provides evidence for a disturbance in iron metabolism in PD (Loeffler et al. 1995). However, lactoferrin has been shown to be increased in PD (Faucheux et al. 1995; Leveugle et al. 1996). There is also evidence that the expression of iron export protein ferroportin is increased in the $\mathrm{SN}$ of $\mathrm{PD}$, while the iron-storage protein ferritin expression is unchanged (Visanji et al. 2013), increased (Riederer et al. 1989) or decreased (Dexter et al. 1991). As all this information is not too convincing for the proof, that a disturbance of iron transport is causally responsible for triggering an increased brain and especially $\mathrm{SN}$ accumulation of iron, the increase of iron in the SN of PD might be secondary to a disturbed BBB as demonstrated in animal models of PD (Oestreicher et al. 1994; Arendash et al. 1993). Increased staining of SN capillaries in postmortem SN as shown in Fig. 2 would be in line with such assumptions and data presented by Faucheux et al. (1999). "Therefore, the driving force of triggering PD might be the continuous uptake of free iron through a disturbed BBB at the site of the substantia nigra (SN). Intraneuronal facilitation of oxidative stress (OS), driven by iron, may disturb mitochondrial respiratory chain activity and may contribute to the generation of fibril a-synuclein (a-syn) and reduction in proteasomal activity. NM-induced toxicity, protein aggregation and generation of Lewy bodies (LB) are the consequence. In addition, glial activation will release several compounds, which enhance and synergistically drive toxic cell death cascades" (Riederer 2004). Evidence for a disturbed BBB comes from studies by Faucheux et al. (1999) and experimental studies using 6-hydroxydopamine,

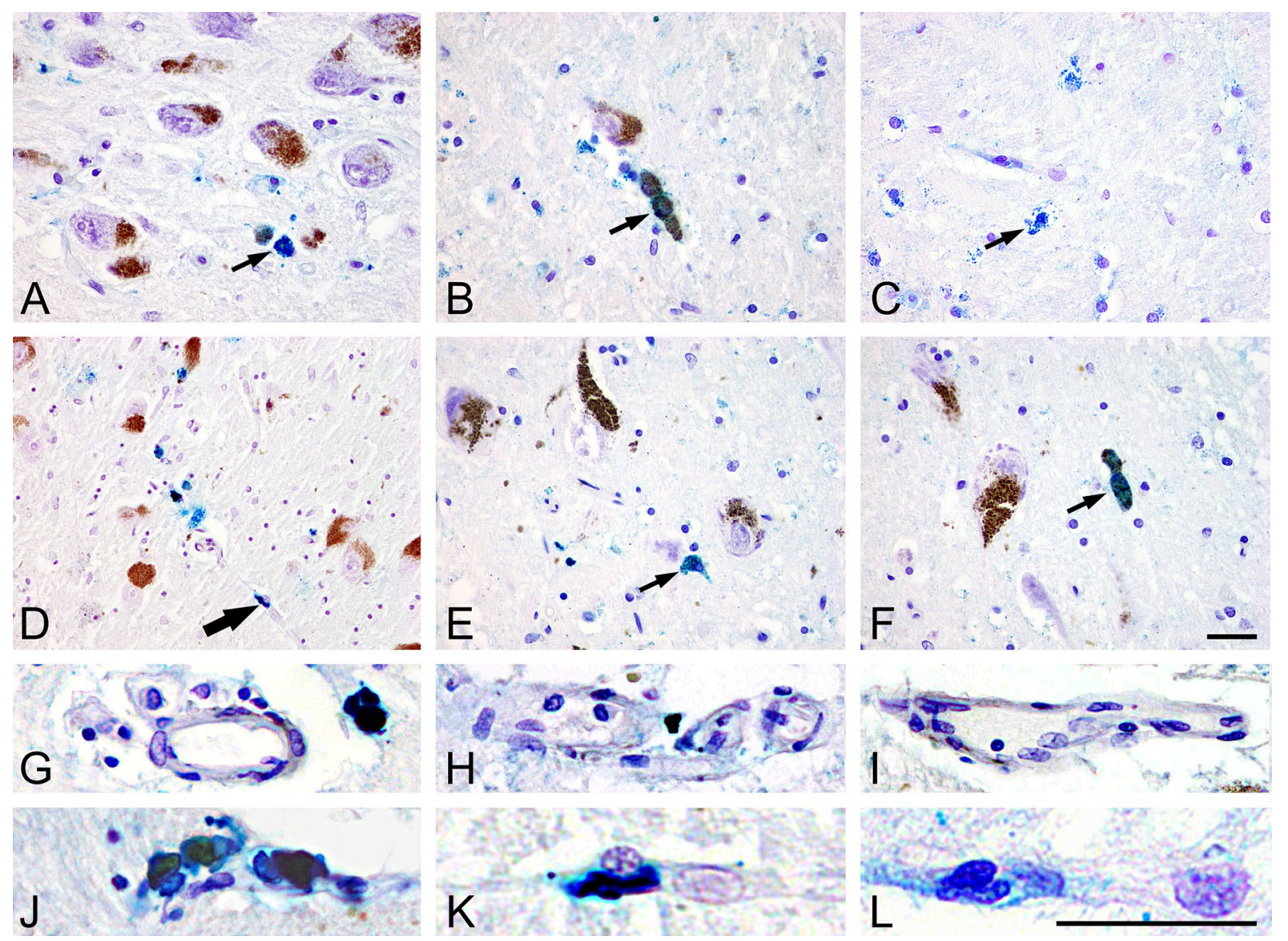

Fig. 2 Detection of iron deposits (Fe III) using Berlin blue reaction: intracytoplasmic fine granules in neuromelanin containing neurons of $\mathrm{SN}$ both in controls (A, B) and in PD cases (D-F) as well in glial cells in controls (C) (thin arrows). Coarsely deposits in capillary walls in PD cases (e.g. D) (thick arrow), whereas in controls (A-C) such reaction is missing $(200 \times$ magnification, scale bar $50 \mu \mathrm{m})$. $G-I$ Iron-free vessels in controls, $J$ - $L$ iron deposits in vessels of PD brains 
showing an increased uptake of iron at the site of the SN (Oestreicher et al. 1994). In addition, binding parameters of the iron-transporting protein transferrin are changed in PD (Gerlach et al. 2006) and an augmented expression of the divalent cation transporter has been shown in SN neurons (Qian and Wang 1998). Also using a unilaterally MPTPtreated monkey model increased iron was found in degenerating dopamine cells, glia and neuron surrounding matrix (Temlett et al. 1994).

Conclusions from this part are

- IRON increases with age.

- IRON transfer through BBB is increased.

- IRON export from brain is increased.

- IRON is increased in SN blood vessels.

- IRON storage by ferritin and neuromelanin is dysregulated.

- Free/labile IRON increases and induces Fenton reaction leading to toxic hydroxyl radicals.

- Ferroptosis causes proteasomal defect, mitochondrial disturbances and cellular cytotoxic processes, lysosomal defects, apoptosis and autophagy dysregulation, all together causing cell degeneration. Ferroptosis is characterized by an accumulation of lipid hydroperoxides (Dixon Scott et al. 2012). The sensitivity to ferroptosis is linked to numerous biological processes and in particular to iron, glutathione, phospholipid, NADPH, coenzyme $\mathrm{Q}_{10}$ and polyunsaturated fatty acid metabolism (Yan and Zhang 2020; Stockwell et al. 2017). A deficient regulation of ferroptosis has been found in MPTP-treated mice (Tapias 2019), a model of PD pathology (Fig. 3).
This scenario seems to be evident for a pathological mechanism in which iron is involved in the progression of PD. However, it cannot be excluded that iron is also a key for triggering PD in the gut/olfactory system as is suggested by the interaction of the type-II transmembrane serine protease TMPRSS6/hepcidin interaction.

\section{Iron related animal models of PD}

The assumption, that iron plays a predominant role in the pathogenesis of dopaminergic cell death in PD has favoured experimental studies to further elucidate pathological mechanisms underlying iron-induced pathology (Sengstock et al. 1992; Wesemann et al. 1994).

As described in detail by Gerlach et al. (2021), the unilateral intranigral injection of ferric iron at a low $\mu \mathrm{g}$ dose causes time-dependent altered motor behaviour in rats, which is accompanied by an average $95 \%$ reduction of the dopamine concentration in the ipsilateral striatum and a smaller reduction of its metabolites 3,4-dihydroxyphenylacetic acid and homovanillic acid. This is accompanied by reactive gliosis, iron-stained astrocytes and activated microglia already early after iron SNpc intoxication (Gerlach et al. 2021). To further elucidate the potential of an NM-ironinduced neurotoxicity, a rat model based on the intranigral injections of human NM-bound ferric iron into the SN has been developed. Injection of a NM-ferric iron suspension $(0.139 \mu \mathrm{g}$ iron) into the ventrolateral region of the left SNpc leads to $50 \%$ reduction of dopamine neuron number eight weeks after injection (Double et al. 2003b; Gerlach et al. 2021). At this dose of iron, no motor abnormalities could be

\section{A: BRAAKS DUAL-HIT- AND BOTTOM-UP- HYPOTHESIS OF NEURONAL CELL DEATH IN PARKINSON'S DISEASE.}

\begin{tabular}{|c|c|c|c|c|}
\hline $\begin{array}{l}\text { VARIOUS } \\
\text { TRIGGERS; }\end{array}$ & BOTTOM-UP & IRON-INDUCED PATHOLOGY & & \\
\hline STRESS & GUI-BKAIN-AXIS & OXIDATIVE STRESS & PROTEIN & BRAIN REGIONAL NEURONAL DEATH \\
\hline & DUAL - HIT & LIPID/PROTEIN OXIDATION & AGGREGATION & CELL DEATH \\
\hline VINGES & $\begin{array}{l}\text {-GASTRO- } \\
\text { INTESTINAL }\end{array}$ & MITOCHONDRIAL & SPREADING VIA & LEWY BODIES \\
\hline BACTERIA & DISTURBANCES & DYSFUNCTION? & VAGAL NERVE & INFLAMMATION \\
\hline CHEMICALS & $\begin{array}{l}\text {-OLFACTORY } \\
\text { SYSTEM }\end{array}$ & $\begin{array}{l}\text { PROTEASOMAL DYSFUNCTION? } \\
\text { INFLAMMATION }\end{array}$ & $\begin{array}{l}\text { OLFACTORY } \\
\text { SYSTEM }\end{array}$ & \\
\hline
\end{tabular}

B: TOP-DOWN-THEORIES FOR THE PATHOLOGY OF PARKINSON'S DISEASE

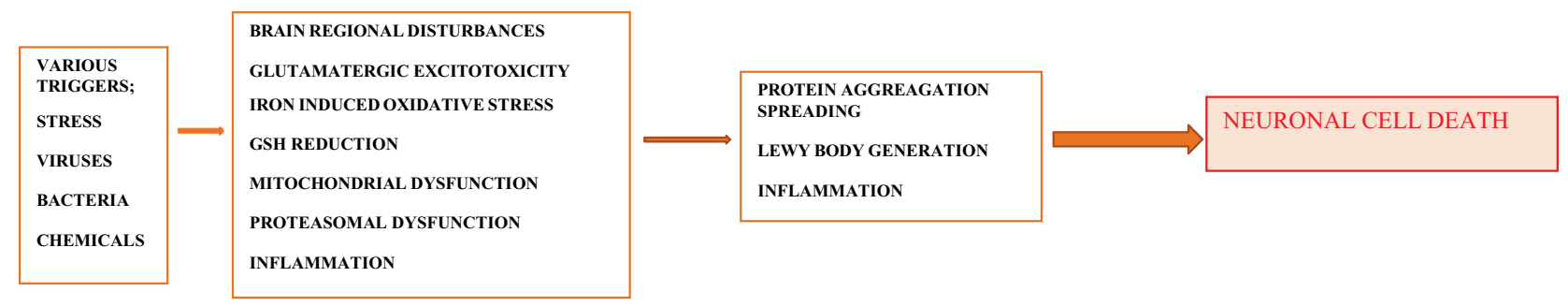

Fig. 3 Pathological events triggering Parkinson's disease 
observed and there was no reduction of dopamine suggesting subclinical dopaminergic lesions under these experimental conditions (Gerlach et al. 2021). Multiple animal studies and experimental work using cell culture systems as described in more detail by Gerlach et al. (2021) confirm that iron and the NM-iron complex are important risk factors for the proper functioning of dopaminergic neurons in the SNpc. However, the notion is of interest, that in PD a significant correlation between dopamine concentration and iron content is relevant only in the putamen but not in the SN (Gerlach et al. 1994). Under physiological conditions the putamen shows high concentrations of dopamine but only rather low levels of iron. This finding is vice versa in the SN. Therefore, one may assume that neither dopamine nor iron alone are primary toxins for the degenerating process related to the putamen and the SN.

As it has been described in more detail (Sian-Hulsmann and Riederer 2021), several hypothesis have been created to elucidate the pathological pathway(s) leading to PD. Braak's "bottom-up hypothesis" (Braak et al. 2003b) claiming, that the pathology spreads in a prion-like manner from the gut via the vagus nerve and/or the olfactory system to brain regions (dual-hit-hypothesis), including the $\mathrm{SNpc}$, has been challenged by Jellinger and others (Jellinger 2019), since only about 50\% PD patients can be related to this pathology. Therefore, other hypotheses have been created to at least fill the gap and to provide evidence for other pathological pathways. One of these more recent hypotheses is the "top-downhypothesis", which postulates a cortical-striatal excitation stress, finally leading to a striato-nigral retrograde process, that includes a-syn pathology (Foffani and Obeso 2018; Urban et al. 2020). Support for this are neuropathological findings showing that early in PD only $30 \%$ of dopaminergic neurons of the SNpc are degenerated but about $60 \%$ of its dendrites (Cheng et al. 2010). A third causal pathology, the "threshold hypothesis", has been forwarded by Engelender and Isacson (Engelender and Isacson 2017), which collectively summarizes a variety of vulnerability factors.

In this respect, it is noteworthy, that already Lhermitte et al. (1924) reported an increase of iron in the globus pallidus (but not in the $\mathrm{SN}$ ) in a patient with PD. This has been confirmed by Dexter et al. (1991) and Griffith et al. (1999) suggesting a possible retrograde pathological process. Indeed, multiple pathological processes and toxin interactions are suggested to be responsible for triggering and processing PD (Hare and Double 2016; Riederer et al. 2019; Sian-Hulsmann et al. 2011). In particular, evidence accumulates, that the risk for triggering pathological processes increases, when there is a high redox load (Berg et al. 2004), e.g. resulting from rather high iron concentration, tyrosine hydroxylase activity and dopamine concentrations, as in the SN (Riederer et al. 1992; Sofic et al. 1992; Gerlach et al. 1994).

\section{Tyrosine hydroxylase-iron relationship}

Rausch et al. (1988) reported on the activity of tyrosine hydroxylase (TH) in post-mortem brain tissue of controls and PD under stimulating conditions in the presence of iron (II) and phosphorylating agents, like cAMP, exogenous protein kinase, calcium plus calmodulin and ATP. TH in control tissue was stimulated by $1 \mathrm{mM}$ iron (II) by 13 -fold. Although the activity of TH in striata of PD was $60 \%$ of controls, stimulation with $1 \mathrm{mM}$ iron (II) reached an 11 -fold increase of TH activity. This finding was similar to that of controls as was the Km-value of TH in controls and PD (Rausch et al. 1988; Riederer et al. 1988). Soluble TH interacts with a-syn and an increase of a-syn leads to reduction of TH activity. Therefore, it is hypothesized that iron-induced enhancement of TH activity by reducing a-syn activity increases dopamine concentration. Furthermore, reaction of dopamine with iron causes a-syn aggregation (Sian-Hulsmann et al. 2015).

\section{Neuromelanin-associated iron toxicity}

$\mathrm{NM}$ is an insoluble complex organic polymer, which is accumulated in neuromelanin granules of various brain regions and most important in the $\mathrm{SN}$ and the locus coeruleus, brain regions, which are predominantly involved in the pathogenesis of PD (Marsden 1983). In fact, Hirsch et al. (1988, 1989) has shown, that it is the NM-containing dopaminergic neurons of the $\mathrm{SN}$, which are primarily degenerating in PD. As such, NM received much interest to elucidate the role of $\mathrm{NM}$ as pathological component of the degenerating process. Here of special importance is NM capacity to bind metals and in particular iron (Gerlach et al. 2021; Youdim et al. 1989). This organic polymer binds iron with a high- and lowaffinity binding characteristic (Ben-Shachar et al. 1991) and NM has been shown to be the major iron-storing structure in neurons while ferritin is located especially in the glia. Of notice is, that intraneuronal iron homeostasis is guaranteed by NM (Ben-Shachar et al. 1991; Youdim et al. 1990, 1989). As determined by Gerlach et al. (1995) in isolated NM from post-mortem SN by Mössbauer spectroscopy iron bound to NM consists exclusively of ferric iron, that is bound to ferritin-like oxyhydroxide cluster (Gerlach et al. 1995, 2021). The notion is of importance, that in dopaminergic neurons iron-mediated oxidation of dopamine might be responsible for the generation of NM (Double et al. 2000; Gerlach et al. 2008; Zecca et al. 2004a; Riederer et al. 2019).

Indeed, there is a long tradition to discuss the question, whether biosynthesis of NM is a spontaneous chemical outoxidation reaction of dopamine/noradrenaline or whether some, but not all TH positive dopaminergic/noradrenergic neurons of the SN/locus coeruleus generate NM via a genetic programme (Zecca et al. 2001; Sulzer et al. 2000; Greggio et al. 2005; Ikemoto et al. 1998; Tribl et al. 2007; 
Carballo-Carbajal et al. 2019; Vila et al. 2019; Bellinger et al. 2011; Xu et al. 1997; Plum et al. 2016). This aspect is challenged by the fact, that (a) not all TH containing dopaminergic neurons generate NM as intraneuronal component (Hirsch et al. 1988, 1989) and (b) that treatment of PD patients with L-DOPA does not increase NM in remaining dopaminergic neurons (Jellinger and Paulus 1992), although it increases dopamine in remaining dopaminergic neurons. This is supported also by experimental studies showing that chronic levodopa is not further aggravating toxicity in rats with a nigrostriatal lesion (Murer et al. 1998). Furthermore, tyrosinase has been shown to be expressed in a subpopulation of dopaminergic neurons (Greggio et al. 2005; Carballo-Carbajal et al. 2019; Zecca et al. 2001; Miranda et al. 1984; Xu et al. 1997; Tief et al. 1998; Higashi et al. 2000) as summarized by Zecca et al. (2001). Tyrosinase has not always been detected in human SN (Ikemoto et al. 1998; Tribl et al. 2007) probably due to low sensitivity of methods used (Carballo-Carbajal et al. 2019). Even if the enzymatic expression seems to be extremely low, this does not exclude the possibility that tyrosinase synthesizes NM in an age-related manner in a subpopulation of dopaminergic neurons in the SN. Biochemical studies unravelling the kinetics of human tyrosinase may shed lights on the characteristics underlying NM biosynthesis (see e.g. Young et al. (2020). Besides tyrosinase, there might be other enzymes able to generate NM. As peroxidase is present in lysosomes, as well as NM, it has been suggested that this enzyme forms NM (Okun 1997). Indeed, peroxidase has been shown to be increased in post-mortem PD brain (De Iuliis et al. 2002). Also, by using subcellular proteomics, glutathione peroxidase 4 (GPX4) has been shown to be colocalized with NM in SN neurons (Tribl et al. 2005). Immunohistochemistry shows that GPX4 is up-regulated in neurons of the SN and associated with dystrophic axons in the striatum of PD (Bellinger et al. 2011) suggesting, that GPX4 colocalizes with alpha-synuclein ( $\alpha$-syn) positive nigral LB and dystrophic TH-positive fibres in the putamen. As glutathione (GSH) is reduced in PD (Dexter et al. 1991; Riederer et al. 1985) and even in ILBD (Dexter et al. 1994) this might indicate a response to OS leading to enhanced NM pathology. Nevertheless, NM protects neurons from excess free iron by its high iron-binding capacity and at least this mechanism operates until saturation of NM is evident (Ben-Shachar et al. 1991; Gerlach et al. 2003; Double 2006; Mochizuki et al. 2020; Mochizuki 1993). Thereafter and by unknown reasons iron may be released and promotes harmful redox reactions (Berg et al. 2004). Here Fenton reaction induced OS has been suggested a major pathological process including reaction with proteins like $\alpha$-syn (Riederer et al. 2019; Shamoto-Nagai et al. 2006; Zucca et al. 2017). The toxicity underlying degenerating processes in the SN of PD seem to include components like $\alpha$-syn, NM, iron as well as dopamine/dopamine oxidation products (Mandel et al. 2004; Riederer et al. 2019). NM increases with ageing (Zucca et al. 2018; Mann and Yates 1983; Vila et al. 2019) and NM deposition is associated with $\alpha$-syn accumulation in aging neurons (Xuan et al. 2011). As in PD there is a greater overall reduction in the amount of melanin within remaining cells (15\% in SN, $25 \%$ in locus coeruleus) because of a more severe $(80 \%)$ loss of heavier pigmented cells, this further contributes to assume a massive disturbance of the iron-NM interaction with the consequence, that iron is set free from NM (Fasano et al. 2006). NM-sensitive imaging displayed reduced NM levels in the ventral $(-30 \pm 28 \%)$ and dorsal tiers $(-21 \pm 24 \%)$ as compared to controls (Martin-Bastida et al. 2017), thus agreeing with imaging studies performed by Pavese and Tai (2018), Hansen et al. (2016), Zupan et al. (2019).

As iron also undergoes an increase during ageing (Zecca et al. 2004a) the risk for a disturbance of iron homeostasis enhances and this may explain the vulnerability of dopaminergic neurons for pathological processes including disruption of endosomal and lysosomal function via multiple mechanisms as described in more detail by Perrett et al. (2015), Tribl et al. (2006), Plum et al. (2016), Isaias et al. (2016), Burbulla and Krainc (2019), Zecca et al. (2008), Carballo-Carbajal et al. (2019), Riederer et al. (2019), Pan et al. (2012). Support for this comes from studies showing both structural changes of NM (Double et al. 2003a) associated with a loss of iron binding to NM in PD (Fasano et al. 2006). Experimental studies using unilateral intranigral injections of ferric iron as well as unilateral injections of human NM-bound ferric iron into the $\mathrm{SN}$ of rats are in line with the suggestion, that the toxic couple NM-iron plays a predominant role in the pathogenesis of $\mathrm{SN}$ related dysfunction and degeneration in PD (Gerlach et al. 2021). In addition, experimental studies in MPTP-lesioned hemi-parkinsonian African Green monkeys show contralateral hemiparkinsonism with significantly elevated iron compared to the unlesioned side (Temlett et al. 1994). In a seminal publication of Kurt Jellinger, he and his co-workers studied human post-mortem SNpc by using a X-ray-microanalysis technique. They found "weak but significant iron peakssimilar to those of synthetic melanin-iron (III) complexonly in intraneuronal highly electron-dense NM-granules of $\mathrm{SNpc}$ cells of PD plus AD. No detectable iron was seen in non-melanized cytoplasm of SNpc neurons and in the adjacent neuropil in PD and controls, in LBs in SNpc neurons of PD" (Jellinger et al. 1992). These findings demonstrated a NM-iron complex in dopaminergic SNpc neurons in PD supporting the idea, that a NM-iron interaction contributes significantly to dopaminergic degeneration in PD and AD (Jellinger et al. 1992; Kienzl et al. 1995). This data in PD has been confirmed by Good et al. (1992) and also recently via magnetic resonance transverse relaxation times $\left(T_{2}\right.$ and 
$\mathrm{T}_{2}{ }^{*}$ ) studies in the SNpc (Lee et al. 2020). An increase in iron levels in the SN of PD by post-mortem $\mathrm{R}_{2}{ }^{*}$ or SWI measurements were observed also by Wang et al. (2016). Mean $\mathrm{R}_{2} *$ in the SNpc defined by NM-sensitive MRI is significantly increased in PD (Martin-Bastida et al. 2017; Priovoulos et al. 2020; Langley et al. 2019; Huddleston et al. 2019). There is general agreement that NM is an excellent chelator of trace elements and especially iron. Therefore, and under physiological conditions NM protects neurons from toxic compounds (Fink et al. 2019; Zucca et al. 2018). In the case of increased iron support, NM may render saturated by iron. If so, excessive iron cannot be bound to NM and may cause generation of free hydroxyl radicals in the cytoplasm, OS with peroxidation of lipids, proteins, like $\alpha$-syn, etc. followed by neurotoxicity, degenerating processes and neuronal loss. Here the notion is of interest, that there is a covalent linkage between $\alpha$-syn and NM from the early stages of the disease on (Halliday et al. 2005; Fasano et al. 2006). More recent findings from a proteomic characterization of human post-mortem NM granules indicate, that about 1,000 proteins are bound and have been identified (Plum et al. 2016). A major question then is, what is the physiological function of TH-positive NM-containing vs. TH positive NM-negative dopaminergic neurons?

\section{General aspects of Parkinson pathology}

PD represents a progressive neurodegenerative disease. It mainly afflicts the older population, although juvenile cases have been reported. The principal pathology of the disorder is characterised by the depletion in striatal dopamine content as a direct consequence of the degeneration of the nigrostriatal tract. The dopamine reduction largely contributes to many of the motor features exhibited by the disease.

There are other neuropathological features such as the presence of intracellular inclusions, LB in the SN and other afflicted areas in the brain. Although LB are not exclusive to PD and have been found in other diseases, nevertheless, its presence in the $\mathrm{SN}$ is paramount for the diagnosis of the illness. Indeed, LB diseases have been considered a spectrum including incidental LB disease, idiopathic PD, dementia with LB and Alzheimer's disease (Jellinger and Korczyn 2018). Interestingly, the prevalence of these structures appears to increase with age from 3.8 to $12.8 \%$ between the sixth and ninth decade (Gibb and Lees 1988b).This concords with the notion that increasing age is predisposing factor in the manifestation of the disorder. Interestingly studies suggest that although there is similar LB pathology in young onset (less than 45 years) and older onset (over 70 years); however, the younger onset group exhibited a greater (24\%) loss in the SN. However, there appears to be some underlying pre-requisite which determines the development of the neurodegenerative disorder. A genetic predisposition may confer vulnerability of the nigral neurons to the onslaught of the mechanisms operational in the illness (Lewis and Cookson 2012).

Increasing evidence supports the involvement of an imbalance or dysfunction of the cellular protein homeostasis as an important factor in the pathogenesis of PD and other related disorders. Indeed, LB comprise mainly of misfolded proteins such as $\alpha$-syn but iron staining can be seen occasionally in the halo of LB (Jellinger et al. 1990). The appearance of these $\alpha$-syn/LB inclusion clearly reflects an inability of the proteasome to degrade these unwanted inclusions and an indisposition of the protein homeostasis system. Subsequently, the cells with $\alpha$-syn affect normal healthy neurons and spread in a prion-like manner, the "host to graft transmission" hypothesis (Recasens et al. 2014).

$\alpha$-syn may exert its destruction via iron mode of cellular toxicity. Indeed, this concept is supported by its ability to function as ferrireductase (Sian-Hulsmann and Riederer 2020). Iron-dependent ferrireductase is involved in iron metabolism and possibly under pathological conditions, it is possible that in the pathological state it might not function at its full capacity and thus build-up total nigral iron in PD. Studies using retinal cells suggest that $\alpha$-syn aggregates, interferes with iron autophagy and blocks its release from ferritin (Baksi and Singh 2017). Interestingly, unusual iron-responsive elements have been reported to be present in the 5'-untranslated region of $\alpha$-syn (Ma et al. 2021), which may contribute to its oligomerisation and aggregation in the more advanced stages of the illness. Indeed, the absence of changes in iron levels in incidental Lewy body disease (Dexter et al. 1994), suggests that the early $\alpha$-syn accumulation and LB formation is not necessarily induced by iron. The precise role of LB in the process of neurodegeneration is still unclear (Jellinger 2014), since its patho-mechanisms are unknown. Therefore, they may represent a cause or a consequence of cell death. In view of their early appearance in the asymptomatic phase of the illness (incidental Lewy body) (Gibb and Lees 1988a) coupled with their appearance in close vicinity in brain area exhibiting neuronal cell carnage, it, therefore, appears highly that $\alpha$-syn plays some ominous role in neuronal destruction and progression. Indeed, in vitro and in vivo studies, suggest that $\alpha$-syn undergoes a conformational change to a toxic form and thus initiating or subscribing to neuronal cell destruction (Lashuel et al. 2013).

Based on its location in the pre-synaptic area, its has, therefore, been suggested that the physiological role of $\alpha$-syn may be in the release of neurotransmitters (Sulzer and Edwards 2019). Whereas, over expression of $\alpha$-syn, appears to block the neurotransmitter release from the synaptic vesicles. Additionally, it is also involved in the regulation of mitochondrial fusion-fission (Bernal-Conde et al. 2020). It appears that $\alpha$-syn is able to conduct physiological functions in the monomeric form. However, misfolding of the protein 
results in the conformational change to the toxic version of $\alpha$-syn (this includes both the phosphorylated and nonphosphorylated form) and the formation of oligomers, which induces mitochondrial malfunction and ultimately triggering patho-mechanisms characteristic to the disease.

Factors such as ageing, genetic predisposition, selective vulnerability of areas in the brain, may contribute to the cellular degeneration capacity of $\alpha$-syn (Wong and Krainc 2017). Indeed, mutations in the $\alpha$-syn/SNCA gene (such as, A30P and A53T) augment the propensity for the $\alpha$-syn to produce protofibrillar intermediates of its toxic oligomers (Bengoa-Vergniory et al. 2017). Perhaps these factors exert an indirect role, such that due to normal ageing coupled with some underlying genetic contribution the cellular protein homeostasis is disrupted, resulting in the accumulation of $\alpha$-syn aggregates and thus the formation of LB. Furthermore, the interactions between $\alpha$-syn and other PD proteins such as ubiquitin ligases encoded by PARK2 and PARK7 genes (Hauser et al. 2017) and kinase proteins, LRKK2 (Harvey and Outeiro 2018), suggest that $\alpha$-syn may execute its pathological role via interaction with other proteins. This notion is also supported by its association with proteins involved in cellular destruction, such as PARK2, which regulates apoptosis and STUB1 that manages cell death (Kalia et al. 2011). Although, familial PD comprises for less than $10 \%$ of the cases, of which not many are related to SNCA mutations, thereby suggesting that the involvement of other factors, thus a collection of conditions, e.g. molecules coupled with an underlying genetic link may all represent key members of the pathogenic orchestra.

Interestingly, there appear to be different forms of $\alpha$-syn protein congregations, which in turn give rise to various synucleinopathies including, PD, MSA and dementia with LB (Peelaerts et al. 2018). Thus, the unique misfolded $\alpha$-syn conformational variants confer to the distinct type of synucleinopathies exhibited. This may be related to the differential accumulation processes and subsequent production of the $\alpha$-syn variants. Additionally, this may also ascribe to the diverse clinical features of these neurodegenerative disorders.

\section{Neuroinflammatory aspects of Parkinson disease}

$\alpha$-syn aggregates have also been implicated in the activation of a chronic state of inflammation in PD (Hirsch 1994; Varanita and Bubacco 2020; Hirsch and Standaert 2021). In fact, the presence of active microgliosis in SN in PD was first suggested in the occurrence of neuroinflammation in the diseases process (McGeer et al. 1988). The microglia under physiological conditions exert a protective function on the brain via neurotrophic secretion. However, in the diseased state they adopt a pathogenic role. Therefore, perhaps a release of NM together with NM-bound components contributing to initiate and worsen an eventual immune response and exacerbating OS and neuroinflammation contributes to the cell death and progression of the disease. Possibly in the early stages of the illness, the nigral cell death may evoke inflammation as a neuroprotective response; however, as the disease progresses, the dying neurons may release inflammatory molecules that contribute to a state of chronic inflammation and consequentially exacerbating the cell destruction. However, it is unclear whether inflammation is primary or secondary to the neurodegeneration (Hirsch and Standaert 2021; Depboylu et al. 2007). It is very likely that there are other factors in addition to neuroinflammation that contribute to the cell death downstream (Halliwell 2006). Indeed, the brain is modestly equipped with anti-oxidant artillery and thus easily assailable and susceptible to get overwhelmed by aggressive degenerative processes such as inflammation, OS, mitochondrial dysfunction and inadequacy of the protein clearance system to destroy unwanted protein aggregates (such as misfolded $\alpha$-syn oligomers).

\section{Glutathione-iron relationship}

A plethora of evidence is indicative of the occurrence of oxidative stress in PD (Götz et al. 1990; Trist et al. 2019), although it is unclear whether it represents a cause or a consequence of the characteristic neurodegeneration observed in the SN. Nevertheless, its cytotoxic pathways and their products carry the lethal potential to evoke cellular destruction. OS is implicated by a host of nigral changes such as, elevation of total iron, increase in monoamine oxidase (MAO A) activity (Tong et al. 2017), changes of aldehyde dehydroxygenase (ALDH) activity (Mandel et al. 2005; Michel et al. 2014), loss of NM, an increase in lipid peroxidation, reduction in the antioxidant glutathione (GSH). It employs ROS or free radicals as leading culprits that interfere with physiological function causing cellular havoc and eventually neuronal destruction in its wake. It has been suggested that the dopamine degradation mechanisms may contribute to the production of ROS. Indeed, the elevation of dopamine metabolic enzyme, MAO A activity and loss of ALDH-1A supports this notion and in addition oxidation of dopamine produces toxic quinones and free radicals. Interestingly, the isoenzyme MAO B activity is increased in the frontal cortex but not in the SN (Tong et al. 2017). The main mode of free radical destruction is, antioxidants. However, no changes were reported in the antioxidant enzymes, total superoxide dismutase (Saggu et al. 1989) and catalase (Jenner et al. 1992a, b). Similarly, there was an absence of the change of activity of glutathione peroxidase (Sian et al. 1994), the enzyme responsible for the conversion of GSH to GSSG, thereby suggesting that the reduction of nigral 
GSH content (Sian 1991) is not due to its conversion to the oxidised form (GSSG), furthermore the GSSG content was unaltered in PD (Sian 1991). Interestingly, a depletion of glutathione appeared to evoke destruction of dopaminergic nigral neurons and protein aggregation in rats (Garrido et al. 2011). GSH is synthesized in both the neurons and the astroglial cells (Dringen and Hirrlinger 2003), although the glia has higher GSH levels compared to neurons since it is able to utilise a larger variety of substrates (Smeyne and Smeyne 2013). Indeed, studies using mercury orange for staining GSH showed reduction of GSH in the surviving neurons in contrast to the microglial cells in PD (Pearce et al. 1997). Perhaps activated glial cells are unable to provide cysteine required for neuronal GSH synthesis, thereby contributing to depletion of the GSH content in the neurons. Therefore, the neurons may be more susceptible to OS. In addition, the cytotoxic molecules released from microgliosis may exacerbate the neuronal damage. This suggests a significant role played by GSH in the neurodegeneration, as demonstrated by its reduction in the early asymptomatic phase of the illness, incidental Lewy body disease (Dexter et al. 1994). The early stages of the illness are marked by a triad of pathological changes including nigral cell loss ( $40 \%$ ), the presence of LB and loss of GSH. Perhaps the GSH serves as a triage and is "consumed" by early cell loss, subsequently the loss of cellular protection of the antioxidant may render the neurons vulnerable to the protein accumulation and cytotoxic free radical mechanisms and OS. Furthermore, in the SN symptomatic phase of the disorder there are more LB inclusions, a greater loss of SN neurons ( $~ 82 \%$, (Iacono et al. 2015)), similar loss in GSH (Dexter et al. 1994), elevation in iron (Riederer et al. 1989) and a reduction in mitochondrial complex 1 (Schapira et al. 1990, 1989). Interestingly, the absence of any remarkable change in GSH loss in the symptomatic phase of PD compared to the asymptomatic phase, is bewildering, particularly in view of the escalation of neuronal cell death. Studies using human neuroblastoma cells suggest that an over expression of $\alpha$-syn appears to alter the antioxidant capacity of GSH-deficient cells (Perfeito et al. 2017). Extrapolation of these findings would suggest, that possibly due to the progressively increasing formation of $\alpha$-syn containing LB coupled with a depletion of GSH in the SN, this somehow compromises antioxidant ability of glutathione, thus implicating $\alpha$-syn oligomers as a potential candidate for initiating neurodegeneration. It has been reported, that the antioxidant GSH is able to form complexes with iron such as FeS-glutaredoxins, that exert an important role in iron metabolism and trafficking (Berndt and Lillig 2017). Therefore, the depletion of nigral GSH in the early stages of the illness (Dexter et al. 1994) may at least in part contribute to the iron dyshomeostasis and subsequent elevation of iron in $\mathrm{PD}$, as discussed above.

\section{Ferritin}

Additionally, since both an increased (Riederer et al. 1988) and a decreased (Dexter et al. 1991) ferritin content in SN in PD have been reported, it is difficult to make any clear deductions. L-ferritin is part of NM granules (Tribl et al. 2009). This finding clearly proves NM/-L-ferritin as exclusive iron storing structure in dopaminergic neurons of the $\mathrm{SN}$. Ferritin is the major iron-binding protein in glial tissue. However, the role of L- and $\mathrm{H}$-ferritin, which are differentially distributed (Connor et al. 1994) and regulated on a post-transcriptional level has not been clarified in detail in human post-mortem tissue (Sammarco et al. 2008). A substantial decrease of L-ferritin concentration has been found in the SN by Connor et al. (1994), Connor and Menzies (1995) and Galazka-Friedman et al. (2004) even in ILBD. In contrast $\mathrm{H}$-ferritin was higher in ILBD and controls (Koziorowski et al. 2007). As the ratio H/L-ferritin is substantially favouring $\mathrm{H}$-ferritin, the different expression of both subtypes in the SN of PD deserves further attention, especially as the L-chain isoform is associated with iron long-term storage and the $\mathrm{H}$-chain isoform predominates high iron-turnover (Boyd et al. 1985), suggesting a different mode of iron handling in the brain. Additionally, the loss of iron chelator, NM, may also be associated with the elevation of nigral iron levels in PD. Consequently, dyshomeostasis of the $\mathrm{Fe}(\mathrm{III})$ : $\mathrm{Fe}$ (II) ratio develops (Sofic et al. 1988), which is another pathognomonic of the disorder. It should be mentioned that Sofic et al. (1988) were interested to measure the total amount of iron in the SN, i.e. free/labile iron, iron bound to neuromelanin and ferritin as well as iron bound to tyrosine hydroxylase or other proteins. Therefore, tissue was pretreated with hydrochloric acid and pepsin. $\mathrm{Fe}(\mathrm{III})$ executes cellular destruction via triggering cytotoxic mechanisms (Minotti and Aust 1987). Indeed, the elevated iron promotes the Fenton and Haber-Weiss reaction and can exacerbate the production of free radicals such as toxic hydroxyl radical species from hydrogen peroxide (Youdim et al. 1993). These reactive species initiate processes such as cellular lipid peroxidation, mitochondrial dysfunction, cell blebbing and eventually destruction of the neuron.

\section{Mitochondrial dysfunction}

Indeed, free radicals can produce damage to mitochondrial DNA resulting in its loss of function (Liu and Chen 2017). Similarly, loss of mitochondrial function can also be produced by mutations in mitochondrial DNA as observed in familial PD. Consequently, disruption of mitochondria function may provoke disastrous events such as reduction of respiratory chain activity reported in PD (Schapira et al. 1989, 1990; Reichmann and Riederer 1989; Mizuno et al. 1989), production of more free radicals, profound effects on iron 
metabolism since mitochondria is involved in the production of haem and iron cluster proteins (Richardson et al. 2010), thereby suggesting that the nigral mitochondrial dysfunction may affect the iron metabolism via activity of ferrireductase/ $\alpha$-syn and subsequently resulting in the elevation of iron in PD. It appears highly likely that the pathological changes in biochemical parameters are closely associated and can prompt the initiation of cellular deleterious mechanisms. Mitochondrial dysfunction generates OS, reduced synthesis of iron-sulphur clusters and activation of iron regulatory protein 1 . By this, accumulation of iron occurs, which causes hydroxyl radical-mediated damage (Muñoz et al. 2016). Additionally, ageing and underlying genetic predisposition are key players that orchestrate pathways. In fact, it has been suggested that $\alpha$-syn accumulations' and ageing can advocate a reduction in mitochondrial sirtuin 3 , which physiologically plays a vital role in mitochondrial function and protection against OS (Park et al. 2020). Misfolded $\alpha$-syn aggregates have the potential to invoke many of the pathological changes reported in PD, thereby endorsing its importance in the pathogenesis of the disorder.

The appearance of these $\alpha$-syn oligomers also suggest a failing protein clearance system, namely the ubiquitin-proteasome pathway. This concept is supported by the presence of p62 in the ubiquitinate aggregate of LB in PD (Zatloukal et al. 2002). Malfunction of p62 would ascribe to the build-up of unnecessary $\alpha$-syn aggregates and LB formation since it executes the breakdown of incorrectly folded proteins. Furthermore, since it regulates protein homeostasis via ubiquitin-proteasome system and autophagy, this therefore highlights $\mathrm{p} 62$ as a focal point in the faulty protein clearance system in the pathology of the illness (Shin et al. 2020). Interestingly, it was reported that rotenone, an inhibitor of the respiratory chain activity, produced overexpression of p62 which was associated with $\alpha$-syn aggregates (Wu et al. 2015). Extrapolation of these finding would suggest a genetic component that induces the overexpression of $\mathrm{p} 62$ and the $\alpha$-syn accumulation and LB formation.

\section{Bacteria- and SARS-CoV-2-iron interaction}

Braak suggested that PD pathology may begin in the periphery spreading to the glossopharyngeal and vagal nerve and to the brain (Braak et al. 2003a). Possibly, micro-bacteria residing in the gut may produce inflammation resulting in aggregation of $\alpha$-syn. Indeed, an imbalance of gut bacteria or a state of dysbiosis may act as pro-inflammatory mediators (Sherer et al. 2003; Dodiya et al. 2020). Mice treated with the complex I inhibitor, rotenone, exhibited (1) intestinal hyperpermeability, (2) glial cells inflammation, (3) increase in $\alpha$-syn levels, (4) an increase of Gram-negative bacteria and (5) OS (Dodiya et al. 2020). Interestingly, there was also a reduction of "anti-inflammatory" bacteria such, Lactobacillus. This protective role may suggest that the bacteria is iron-independent similar to Lactobacillus plantarum (Archibald and Fridovich 1983), although iron is closely associated to most gut microbiota since it is vital for the propagation and survival of bacteria. Furthermore, it appears that iron may execute a rather ambivalent role, since low dietary iron appeared to produce dysbiosis of gut bacteria (Dostal et al. 2013). Conversely, an iron rich environment appears to support the growth of pathogenic bacteria such as Proteobacteria and induce inflammation (Jaeggi et al. 2015; Xiang et al. 2020).

Nevertheless, an association between iron, specific gut bacteria and inflammation is evident. It is likely that in PD the gut iron levels are elevated and this may produce OS, a state of dysbiosis and reproduction of bacteria that induce $\alpha$-syn modification and inflammation. The inflammation may alter the environmental $\mathrm{pH}$ which may induce the $\alpha$-syn misfolding and aggregation (Meade et al. 2019; Fitzgerald et al. 2019). Subsequently, these $\alpha$-syn accumulations may then be transported and deposited from gut via the vagus nerve to the brain in a retrograde and time-dependent manner. Indeed, $\alpha$-syn aggregates from PD brain lysate injected into the submucosa of the enteric nervous system of mice endorsed this notion (Holmqvist et al. 2014; Fitzgerald et al. 2019). The dual-hit hypothesis suggests that a potential pathogen may enter the brain through the gut and the olfactory system and a two-way communication exists between the microbiota in the periphery and central nervous system (Perez-Pardo et al. 2017). Additionally, a disturbed microbiota gut-brain axis may advocate a pathogenic role via triggering inflammation, $\alpha$-syn oligomerisation and OS in PD. Interestingly, iron homeostasis and microbiota are said to be significant in eliciting intestinal inflammation (Yilmaz and Li 2018). Therefore, the notion is of interest, that even viruses selectively infect iron-acquiring cells or interact with cellular iron metabolism, including hepcidin cells (Schmidt 2020). Hepcidin is a central regulator of systemic iron homeostasis (Nemeth and Ganz 2009). SARS-CoV-2 interacts with haemoglobin through CD 147, CD 26 and other receptors on erythrocyte and/or blood cell precursors and via hepcidinmimetic action of a viral spike protein, including ferroportin blockade (Cavezzi et al. 2020). Furthermore, SARS-CoV2-induced COVID-19 manifests in inflammation, immune dysfunction and hyperferritinemia suggesting iron overload (Habib et al. 2021). Gastrointestinal symptoms are frequent in patients with COVID-19 (Villapol 2020; Huang et al. 2021; Weng et al. 2021; Buscarini et al. 2020; Xiang et al. 2020; Riederer and Meulen 2020; Vetter et al. 2020). For long time, iron-binding proteins like transferrin, lactoferrin and ferritin have been associated with cells of the immune system, and regulatory effects of metals on immune cells, including iron, have been suggested to cause toxic effects 
(Brock and de Sousa 1986). SARS-CoV-2 binds to ACE-2 and the type-II transmembrane serine proteases TMPRSS2 at the body's epithelial cells. Furthermore, TMPRSS11D and TMPRSS13 activate the SARS-CoV-2 spike protein (Kishimoto et al. 2021). Other type-2-transmembrane serine proteases have not been studied so far on the replication of SARS-CoV-2. TMPRSS 6 gene is related to the generation of the protein matriptase-2 (Ramsay et al. 2009), which controls hepcidin biosynthesis and by this iron homeostasis. Indeed, a distant sequence similarity between the cysteinerich cytoplasmic tail of the coronavirus spike protein and the hepcidin protein has been described recently (Ehsani 2020). Therefore, it is not farfetched to assume, that iron homeostasis is disturbed in various organs due to viral infection and thus contributes to the pathology induced by SARS-CoV-2. Indeed, Nai et al. (2021) in a clinical study involving 111 COVID -19 patients showed that serum iron was extremely low in most cases and that this finding was a predictor of mortality. Conversely, hepcidin levels were significantly increased in $61.3 \%$ of patients. Patients with higher hepcidin levels were significantly older and had higher concentrations of markers of inflammation, i.e. CRP and ferritin and cell damage, like LDH. Low serum levels of iron and increased concentrations of both ferritin and hepcidin are characteristic markers of patients with COVID-19 infection (Sonnweber et al. 2020; Hippchen et al. 2020; Cavezzi et al. 2020; Cheng et al. 2020; Henry et al. 2020; Nai et al. 2021; Girelli et al. 2021; Mahat et al. 2021).

In addition, iron deficiency was still present 60 days after disease onset in $30 \%$ of subjects. Anaemic patients (9\%) had increased markers of inflammation (IL-6, C-reactive protein). Hyperferritinemia was still present in $38 \%$ of all individuals and was more frequent in severe or critical COVID-19 (Sonnweber et al. 2020). Hepcidin is rapidly and potently stimulated by pro-inflammatory cytokines like IL-6, leading to hypoferremia, impaired haemoglobin synthesis causing anaemia or inflammation (Girelli et al. 2021; Nai et al. 2021).

As SARS-CoV-2 seems to have hepcidin-like action, the virus can directly increase ferritin levels. Furthermore, the release of iron may be secondary to the interaction between SARS-CoV-2 and haemoglobin and this may cause high ferritin concentration (Garrick and Ghio 2021; Abobaker 2021). Indirect evidence of altered iron homeostasis comes from clinical studies in optimal individualized therapy plus deep brain stimulated patients with PD. Here blood levels of hepcidin and IL-6 concentrations in blood were significantly elevated, indicating neuroinflammatory induced disturbances of peripheral iron homeostasis (Kwiatek-Majkusiak et al. 2020). It is suggested, that more attention should be given to the interaction of iron with SARS-CoV-2 and other viruses. Such studies may contribute to understand the viral toxicity on organs functions. In the 6-hydroxydopamine- as well as in the rotenone-induced PD models overexpression of hepcidin suppressed major pathologies of parkinsonism, protected rotenone-induced mitochondrial deficits and reduced $\alpha$-syn accumulation through a decrease of iron (Liang et al. 2020). Interleukin-6, which is significantly increased in the SN of PD (Mogi et al. 1994) and chronic inflammation (Hirsch and Standaert 2021) increases hepcidin levels (Camaschella et al. 2020). Therefore, the interplay of hepcidin, iron-transport proteins like transferrin, lactoferrin and ferroportin and ironstoring ferritin as well as NM controlling the concentration of free as well as bound/stored iron is a critical factor in the pathology of PD (Vila 2019). Therefore, chelation of excess peripheral free iron as well as excess of $\mathrm{SN}$ free/labile iron with iron chelators, which cross the BBB only at the site of SN BBB disturbance, we suggest to be potential targets for new drug developments to causally influence the ironinduced pathology of PD.

Funding Open Access funding enabled and organized by Projekt DEAL.

Open Access This article is licensed under a Creative Commons Attribution 4.0 International License, which permits use, sharing, adaptation, distribution and reproduction in any medium or format, as long as you give appropriate credit to the original author(s) and the source, provide a link to the Creative Commons licence, and indicate if changes were made. The images or other third party material in this article are included in the article's Creative Commons licence, unless indicated otherwise in a credit line to the material. If material is not included in the article's Creative Commons licence and your intended use is not permitted by statutory regulation or exceeds the permitted use, you will need to obtain permission directly from the copyright holder. To view a copy of this licence, visit http://creativecommons.org/licenses/by/4.0/.

\section{References}

Abobaker A (2021) Reply: Iron chelation may harm patients with COVID-19. Eur J Clin Pharmacol 77(2):267-268. https://doi. org/10.1007/s00228-020-02988-9

Archibald FS, Fridovich I (1983) Oxygen radicals, oxygen toxicity and the life of microorganisms. Acta Med Port 4(2):101-112

Arendash GW, Olanow CW, Sengstock GJ (1993) Iron in Central Nervous System Disorders. Intranigral iron infusion in rats: a progressive model for excess nigral iron levels in Parkinson's disease? Springer, Vienna. https://doi.org/10.1007/978-3-7091-9322-8_8

Ayton S, Lei P, McLean C, Bush AI, Finkelstein DI (2016) Transferrin protects against parkinsonian neurotoxicity and is deficient in Parkinson's substantia nigra. Signal Transduct Target Ther 1:16015. https://doi.org/10.1038/sigtrans.2016.15

Baksi S, Singh N (2017) alpha-Synuclein impairs ferritinophagy in the retinal pigment epithelium: Implications for retinal iron dyshomeostasis in Parkinson's disease. Sci Rep 7(1):12843. https://doi. org/10.1038/s41598-017-12862-x

Bartzokis G, Cummings JL, Markham CH, Marmarelis PZ, Treciokas LJ, Tishler TA, Marder SR, Mintz J (1999) MRI evaluation of brain iron in earlier- and later-onset Parkinson's disease and 
normal subjects. Magn Reson Imaging 17(2):213-222. https:// doi.org/10.1016/s0730-725x(98)00155-6

Becker G, Seufert J, Bogdahn U, Reichmann H, Reiners K (1995) Degeneration of substantia nigra in chronic Parkinson's disease visualized by transcranial color-coded real-time sonography. Neurology 45(1):182-184. https://doi.org/10.1212/wnl.45.1.182

Bellinger FP, Bellinger MT, Seale LA, Takemoto AS, Raman AV, Miki T, Manning-Bog AB, Berry MJ, White LR, Ross GW (2011) Glutathione Peroxidase 4 is associated with neuromelanin in substantia nigra and dystrophic axons in putamen of Parkinson's brain. Mol Neurodegener 6(1):8. https://doi.org/10.1186/ 1750-1326-6-8

Bengoa-Vergniory N, Roberts RF, Wade-Martins R, Alegre-Abarrategui J (2017) Alpha-synuclein oligomers: a new hope. Acta Neuropathol 134(6):819-838. https://doi.org/10.1007/ s00401-017-1755-1

Ben-Shachar D, Riederer P, Youdim MB (1991) Iron-melanin interaction and lipid peroxidation: implications for Parkinson's disease. J Neurochem 57(5):1609-1614. https://doi.org/10.1111/j.14714159.1991.tb06358.x

Berg D (2011) Hyperechogenicity of the substantia nigra: pitfalls in assessment and specificity for Parkinson's disease. J Neural Transm (vienna) 118(3):453-461. https://doi.org/10.1007/ s00702-010-0469-5

Berg D, Becker G, Zeiler B, Tucha O, Hofmann E, Preier M, Benz P, Jost W, Reiners K, Lange KW (1999) Vulnerability of the nigrostriatal system as detected by transcranial ultrasound. Neurology 53(5):1026-1031. https://doi.org/10.1212/wnl.53.5.1026

Berg D, Youdim MBH, Riederer P (2004) Redox imbalance. Cell Tissue Res 318(1):201-213. https://doi.org/10.1007/ s00441-004-0976-5

Berg D, Merz B, Reiners K, Naumann M, Becker G (2005) Five-year follow-up study of hyperechogenicity of the substantia nigra in Parkinson's disease. Mov Disord 20(3):383-385. https://doi.org/ 10.1002/mds.20311

Berg D, Seppi K, Behnke S, Liepelt I, Schweitzer K, Stockner H, Wollenweber F, Gaenslen A, Mahlknecht P, Spiegel J, Godau J, Huber H, Srulijes K, Kiechl S, Bentele M, Gasperi A, Schubert T, Hiry T, Probst M, Schneider V, Klenk J, Sawires M, Willeit J, Maetzler W, Fassbender K, Gasser T, Poewe W (2011) Enlarged substantia nigra hyperechogenicity and risk for Parkinson disease: a 37-month 3-center study of 1847 older persons. Arch Neurol 68(7):932-937. https://doi.org/10.1001/archneurol.2011. 141

Bernal-Conde LD, Ramos-Acevedo R, Reyes-Hernández MA, Balbuena-Olvera AJ, Morales-Moreno ID, Argüero-Sánchez R, Schüle B, Guerra-Crespo M (2020) Alpha-synuclein physiology and pathology: a perspective on cellular structures and organelles. Front Neurosci 13:1399. https://doi.org/10.3389/ fnins.2019.01399

Berndt C, Lillig CH (2017) Glutathione, glutaredoxins, and iron. Antioxid Redox Signal 27(15):1235-1251. https://doi.org/10.1089/ ars.2017.7132

Blazejewska AI, Schwarz ST, Pitiot A, Stephenson MC, Lowe J, Bajaj N, Bowtell RW, Auer DP, Gowland PA (2013) Visualization of nigrosome 1 and its loss in PD: pathoanatomical correlation and in vivo 7 T MRI. Neurology 81(6):534-540. https://doi.org/10. 1212/WNL.0b013e31829e6fd2

Blazejewska AI, Al-Radaideh AM, Wharton S, Lim SY, Bowtell RW, Constantinescu CS, Gowland PA (2015) Increase in the iron content of the substantia nigra and red nucleus in multiple sclerosis and clinically isolated syndrome: a 7 Tesla MRI study. J Magn Reson Imaging 41(4):1065-1070. https://doi.org/10.1002/jmri. 24644

Boyd D, Vecoli C, Belcher DM, Jain SK, Drysdale JW (1985) Structural and functional relationships of human ferritin $\mathrm{H}$ and $\mathrm{L}$ chains deduced from cDNA clones. J Biol Chem 260(21):1175511761. https://doi.org/10.1016/S0021-9258(17)39094-4

Braak H, Del Tredici K, Rüb U, de Vos RA, Jansen Steur EN, Braak E (2003a) Staging of brain pathology related to sporadic Parkinson's disease. Neurobiol Aging 24(2):197-211. https://doi.org/ 10.1016/s0197-4580(02)00065-9

Braak H, Rub U, Gai WP, Del Tredici K (2003b) Idiopathic Parkinson's disease: possible routes by which vulnerable neuronal types may be subject to neuroinvasion by an unknown pathogen. J Neural Transm (vienna) 110(5):517-536. https://doi.org/10.1007/ s00702-002-0808-2

Brock JH, de Sousa M (1986) Immunoregulation by iron-binding proteins. Immunol Today 7(2):30-31. https://doi.org/10.1016/ 0167-5699(86)90117-9

Burbulla LF, Krainc D (2019) The role of dopamine in the pathogenesis of GBA1-linked Parkinson's disease. Neurobiol Dis 132:104545. https://doi.org/10.1016/j.nbd.2019.104545

Buscarini E, Manfredi G, Brambilla G, Menozzi F, Londoni C, Alicante S, Iiritano E, Romeo S, Pedaci M, Benelli G, Canetta C, La Piana G, Merli G, Scartabellati A, Viganò G, Sfogliarini R, Melilli G, Assandri R, Cazzato D, Rossi DS, Usai S, Tramacere I, Pellegata G, Lauria G (2020) GI symptoms as early signs of COVID-19 in hospitalised Italian patients. Gut 69(8):1547. https://doi.org/10.1136/gutjnl-2020-321434

Camaschella C, Nai A, Silvestri L (2020) Iron metabolism and iron disorders revisited in the hepcidin era. Haematologica 105(2):260 272. https://doi.org/10.3324/haematol.2019.232124

Carballo-Carbajal I, Laguna A, Romero-Gimenez J, Cuadros T, Bove J, Martinez-Vicente M, Parent A, Gonzalez-Sepulveda M, Penuelas N, Torra A, Rodriguez-Galvan B, Ballabio A, Hasegawa T, Bortolozzi A, Gelpi E, Vila M (2019) Brain tyrosinase overexpression implicates age-dependent neuromelanin production in Parkinson's disease pathogenesis. Nat Commun 10(1):973. https://doi.org/10.1038/s41467-019-08858-y

Cavezzi A, Troiani E, Corrao S (2020) COVID-19: hemoglobin, iron, and hypoxia beyond inflammation. A narrative review. Clin Practice 10(2):24-30

Chen Q, Chen Y, Zhang Y, Wang F, Yu H, Zhang C, Jiang Z, Luo W (2019) Iron deposition in Parkinson's disease by quantitative susceptibility mapping. BMC Neurosci 20(1):23. https://doi.org/ 10.1186/s12868-019-0505-9

Cheng HC, Ulane CM, Burke RE (2010) Clinical progression in Parkinson disease and the neurobiology of axons. Ann Neurol 67(6):715-725. https://doi.org/10.1002/ana.21995

Cheng L, Li H, Li L, Liu C, Yan S, Chen H, Li Y (2020) Ferritin in the coronavirus disease 2019 (COVID-19): a systematic review and meta-analysis. J Clin Lab Anal 34(10):e23618. https://doi. org/10.1002/jcla.23618

Connor JR, Menzies SL (1995) Cellular management of iron in the brain. J Neurol Sci 134(Suppl):33-44. https://doi.org/10.1016/ 0022-510x(95)00206-h

Connor JR, Boeshore KL, Benkovic SA, Menzies SL (1994) Isoforms of ferritin have a specific cellular distribution in the brain. J Neurosci Res 37(4):461-465. https://doi.org/10.1002/jnr.490370405

Dashtipour K, Liu M, Kani C, Dalaie P, Obenaus A, Simmons D, Gatto NM, Zarifi M (2015) Iron Accumulation Is Not Homogenous Among Patients With Parkinson's disease. Parkinsons Dis 2015:324843. https://doi.org/10.1155/2015/324843

De Iuliis A, Burlina AP, Boschetto R, Zambenedetti P, Arslan P, Galzigna L (2002) Increased dopamine peroxidation in postmortem Parkinsonian brain. Biochim Biophys Acta 1573(1):63-67. https://doi.org/10.1016/s0304-4165(02)00331-8

Depboylu C, Matusch A, Tribl F, Zoriy M, Michel PP, Riederer P, Gerlach M, Becker S, Oertel WH, Höglinger GU (2007) Glia protects neurons against extracellular human neuromelanin. Neurodegener Dis 4(2-3):218-226. https://doi.org/10.1159/000101846 
Dexter DT, Wells FR, Agid F, Agid Y, Lees AJ, Jenner P, Marsden CD (1987) Increased nigral iron content in postmortem parkinsonian brain. Lancet 2(8569):1219-1220. https://doi.org/10.1016/s01406736(87)91361-4

Dexter DT, Carayon A, Javoy-Agid F, Agid Y, Wells FR, Daniel SE, Lees AJ, Jenner P, Marsden CD (1991) Alterations in the levels of iron, ferritin and other trace metals in Parkinson's disease and other neurodegenerative diseases affecting the basal ganglia. Brain 114(Pt 4):1953-1975. https://doi.org/10.1093/brain/ 114.4.1953

Dexter DT, Sian J, Rose S, Hindmarsh JG, Mann VM, Cooper JM, Wells FR, Daniel SE, Lees AJ, Schapira AH et al (1994) Indices of oxidative stress and mitochondrial function in individuals with incidental Lewy body disease. Ann Neurol 35(1):38-44. https:// doi.org/10.1002/ana.410350107

Dixon Scott J, Lemberg Kathryn M, Lamprecht Michael R, Skouta R, Zaitsev Eleina M, Gleason Caroline E, Patel Darpan N, Bauer Andras J, Cantley Alexandra M, Yang Wan S, Morrison B, Stockwell Brent R (2012) Ferroptosis: an iron-dependent form of nonapoptotic cell death. Cell 149(5):1060-1072. https://doi. org/10.1016/j.cell.2012.03.042

Dodiya HB, Forsyth CB, Voigt RM, Engen PA, Patel J, Shaikh M, Green SJ, Naqib A, Roy A, Kordower JH, Pahan K, Shannon KM, Keshavarzian A (2020) Chronic stress-induced gut dysfunction exacerbates Parkinson's disease phenotype and pathology in a rotenone-induced mouse model of Parkinson's disease. Neurobiol Dis 135:104352. https://doi.org/10.1016/j.nbd.2018.12.012

Dostal A, Fehlbaum S, Chassard C, Zimmermann MB, Lacroix C (2013) Low iron availability in continuous in vitro colonic fermentations induces strong dysbiosis of the child gut microbial consortium and a decrease in main metabolites. FEMS Microbiol Ecol 83(1):161-175. https://doi.org/10.1111/j.1574-6941.2012. 01461.x

Double KL (2006) Functional effects of neuromelanin and synthetic melanin in model systems. J Neural Transm (vienna, Austria 1996) 113(6):751-756. https://doi.org/10.1007/ s00702-006-0450-5

Double KL, Gerlach M, Youdim MB, Riederer P (2000) Impaired iron homeostasis in Parkinson's disease. J Neural Transm Suppl 60:37-58. https://doi.org/10.1007/978-3-7091-6301-6_3

Double KL, Gerlach M, Schunemann V, Trautwein AX, Zecca L, Gallorini M, Youdim MB, Riederer P, Ben-Shachar D (2003a) Ironbinding characteristics of neuromelanin of the human substantia nigra. Biochem Pharmacol 66(3):489-494. https://doi.org/10. 1016/s0006-2952(03)00293-4

Double KL, Halliday GM, Henderson J, Griffiths FM, Heinemann T, Riederer P, Gerlach M (2003b) The dopamine receptor agonist lisuride attenuates iron-mediated dopaminergic neurodegeneration. Exp Neurol 184(1):530-535. https://doi.org/10.1016/j. expneurol.2003.08.006

Drayer BP, Olanow W, Burger P, Johnson GA, Herfkens R, Riederer S (1986) Parkinson plus syndrome: diagnosis using high field MR imaging of brain iron. Radiology 159(2):493-498. https://doi. org/10.1148/radiology.159.2.3961182

Dringen R, Hirrlinger J (2003) Glutathione pathways in the brain. Biol Chem 384(4):505-516. https://doi.org/10.1515/BC.2003.059

Earle KM (1968) Studies on Parkinson's disease including X-ray fluorescent spectroscopy of formalin fixed brain tissue. J Neuropathol Exp Neurol 27(1):1-14. https://doi.org/10.1097/00005072-19680 1000-00001

Ehsani S (2020) COVID-19 and iron dysregulation: distant sequence similarity between hepcidin and the novel coronavirus spike glycoprotein. Biol Direct 15(1):19. https://doi.org/10.1186/ s13062-020-00275-2
Engelender S, Isacson O (2017) The threshold theory for Parkinson's disease. Trends Neurosci 40(1):4-14. https://doi.org/10.1016/j. tins.2016.10.008

Fasano M, Bergamasco B, Lopiano L (2006) Modifications of the iron-neuromelanin system in Parkinson's disease. J Neurochem 96(4):909-916. https://doi.org/10.1111/j.1471-4159.2005. 03638.x

Faucheux BA, Nillesse N, Damier P, Spik G, Mouatt-Prigent A, Pierce A, Leveugle B, Kubis N, Hauw JJ, Agid Y et al (1995) Expression of lactoferrin receptors is increased in the mesencephalon of patients with Parkinson disease. Proc Natl Acad Sci USA 92(21):9603-9607. https://doi.org/10.1073/pnas.92.21.9603

Faucheux BA, Bonnet AM, Agid Y, Hirsch EC (1999) Blood vessels change in the mesencephalon of patients with Parkinson's disease. Lancet 353(9157):981-982. https://doi.org/10.1016/S01406736(99)00641-8

Feraco P, Gagliardo C, La Tona G, Bruno E, D’Angelo C, Marrale M, Del Poggio A, Malaguti MC, Geraci L, Baschi R, Petralia B, Midiri M, Monastero R (2021) Imaging of substantia nigra in Parkinson's disease: a narrative review. Brain Sci 11:6. https:// doi.org/10.3390/brainsci11060769

Fink J, Pathak H, Smith J, Achat-Mendes C, Haining RL (2019) Development of a competition-binding assay to determine binding affinity of molecules to neuromelanin via fluorescence spectroscopy. Biomolecules 9:5. https://doi.org/10.3390/biom9050175

Fitzgerald E, Murphy S, Martinson HA (2019) Alpha-synuclein pathology and the role of the microbiota in Parkinson's disease. Front Neurosci 13:369. https://doi.org/10.3389/fnins.2019.00369

Foffani G, Obeso JA (2018) A cortical pathogenic theory of Parkinson's disease. Neuron 99(6):1116-1128. https://doi.org/10. 1016/j.neuron.2018.07.028

Friedman A, Galazka-Friedman J (2012) The history of the research of iron in parkinsonian substantia nigra. J Neural Transm (vienna) 119(12):1507-1510. https://doi.org/10.1007/s00702-012-0894-8

Friedman A, Galazka-Friedman J, Koziorowski D (2009) Iron as a cause of Parkinson disease - a myth or a well established hypothesis? Parkinsonism Relat Disord 15:S212-S214. https://doi.org/ 10.1016/S1353-8020(09)70817-X

Galazka-Friedman J, Bauminger ER, Friedman A, Barcikowska M, Hechel D, Nowik I (1996) Iron in parkinsonian and control substantia nigra-a Mossbauer spectroscopy study. Mov Disord 11(1):8-16. https://doi.org/10.1002/mds.870110104

Galazka-Friedman J, Bauminger ER, Koziorowski D, Friedman A (2004) Mossbauer spectroscopy and ELISA studies reveal differences between Parkinson's disease and control substantia nigra. Biochim Biophys Acta 1688(2):130-136. https://doi.org/ 10.1016/j.bbadis.2003.11.005

Gałazka-Friedman J, Bauminger ER, Friedman A, Barcikowska M, Hechel D, Nowik I (1996) Iron in parkinsonian and control substantia nigra-a Mössbauer spectroscopy study. Mov Disord 11(1):8-16. https://doi.org/10.1002/mds.870110104

Garrick MD, Ghio AJ (2021) Iron chelation may harm patients with COVID-19. Eur J Clin Pharmacol 77(2):265-266. https://doi.org/ 10.1007/s00228-020-02987-w

Garrido M, Tereshchenko Y, Zhevtsova Z, Taschenberger G, Bähr M, Kügler S (2011) Glutathione depletion and overproduction both initiate degeneration of nigral dopaminergic neurons. Acta Neuropathol 121(4):475-485. https://doi.org/10.1007/ s00401-010-0791-x

Gellein K, Flaten TP, Erikson KM, Aschner M, Syversen T (2008) Leaching of trace elements from biological tissue by formalin fixation. Biol Trace Elem Res 121(3):221-225. https://doi.org/ 10.1007/s12011-007-8051-1

Genoud S, Senior AM, Hare DJ, Double KL (2020) Meta-analysis of copper and iron in Parkinson's disease brain and biofluids. Move Disord 35(4):662-671. https://doi.org/10.1002/mds.27947 
Gerlach M, Ben-Shachar D, Riederer P, Youdim MBH (1994) Altered brain metabolism of iron as a cause of neurodegenerative diseases? J Neurochem 63(3):793-807. https://doi.org/10.1046/j. 1471-4159.1994.63030793.x

Gerlach M, Trautwein AX, Zecca L, Youdim MB, Riederer P (1995) Mossbauer spectroscopic studies of purified human neuromelanin isolated from the substantia nigra. J Neurochem 65(2):923926. https://doi.org/10.1046/j.1471-4159.1995.65020923.x

Gerlach M, Double KL, Ben-Shachar D, Zecca L, Youdim MBH, Riederer P (2003) Neuromelanin and its interaction with iron as a potential risk factor for dopaminergic neurodegeneration underlying Parkinson's disease. Neurotox Res 5(1):35-43. https://doi. org/10.1007/BF03033371

Gerlach M, Double KL, Götz ME, Youdim MBH, Riederer P (2006) The role of iron in the pathogenesis of Parkinsons's disease. Metal Ions Life Sci 1:125-149

Gerlach M, Riederer P, Double KL (2008) Neuromelanin-bound ferric iron as an experimental model of dopaminergic neurodegeneration in Parkinson's disease. Parkinsonism Relat Disord 14(Suppl 2):S185-188. https://doi.org/10.1016/j.parkreldis.2008.04.028

Gerlach M, Double KL, Riederer P (2021) Iron-induced cell death in vivo as a model of Parkinson's disease. Handb Neurotoxicity (in press)

Gibb WR, Lees AJ (1988a) A comparison of clinical and pathological features of young- and old-onset Parkinson's disease. Neurology 38(9):1402-1406. https://doi.org/10.1212/wnl.38.9.1402

Gibb WR, Lees AJ (1988b) The relevance of the Lewy body to the pathogenesis of idiopathic Parkinson's disease. J Neurol Neurosurg Psychiatry 51(6):745. https://doi.org/10.1136/jnnp.51.6.745

Girelli D, Marchi G, Busti F, Vianello A (2021) Iron metabolism in infections: focus on COVID-19. Semin Hematol 58(3):182-187. https://doi.org/10.1053/j.seminhematol.2021.07.001

Good PF, Olanow CW, Perl DP (1992) Neuromelanin-containing neurons of the substantia nigra accumulate iron and aluminum in Parkinson's disease: a LAMMA study. Brain Res 593(2):343346. https://doi.org/10.1016/0006-8993(92)91334-b

Götz ME, Freyberger A, Riederer P (1990) Oxidative stress: a role in the pathogenesis of Parkinson's disease. In: Youdim MBH, Tipton KF (eds) Neurotransmitter actions and interactions: proceedings of a satellite symposium of the 12th international society for neurochemistry meeting, Algarve, Portugal. Springer, Vienna, pp 241-249. https://doi.org/10.1007/978-3-7091-9050-0_23

Graham JM, Paley MN, Grunewald RA, Hoggard N, Griffiths PD (2000) Brain iron deposition in Parkinson's disease imaged using the PRIME magnetic resonance sequence. Brain 123(Pt 12):2423-2431. https://doi.org/10.1093/brain/123.12.2423

Greggio E, Bergantino E, Carter D, Ahmad R, Costin GE, Hearing VJ, Clarimon J, Singleton A, Eerola J, Hellstrom O, Tienari PJ, Miller DW, Beilina A, Bubacco L, Cookson MR (2005) Tyrosinase exacerbates dopamine toxicity but is not genetically associated with Parkinson's disease. J Neurochem 93(1):246-256. https://doi.org/10.1111/j.1471-4159.2005.03019.x

Griffiths PD, Dobson BR, Jones GR, Clarke DT (1999) Iron in the basal ganglia in Parkinson's disease. An in vitro study using extended $\mathrm{X}$-ray absorption fine structure and cryo-electron microscopy. Brain 122(4):667-673. https://doi.org/10.1093/brain/122.4.667

Haacke EM, Cheng NY, House MJ, Liu Q, Neelavalli J, Ogg RJ, Khan A, Ayaz M, Kirsch W, Obenaus A (2005) Imaging iron stores in the brain using magnetic resonance imaging. Magn Reson Imaging 23(1):1-25. https://doi.org/10.1016/j.mri.2004.10.001

Habib HM, Ibrahim S, Zaim A, Ibrahim WH (2021) The role of iron in the pathogenesis of COVID-19 and possible treatment with lactoferrin and other iron chelators. Biomed Pharmacother 136:111228. https://doi.org/10.1016/j.biopha.2021.111228
Hallgren B, Sourander P (1958) The effect of age on the non-haemin iron in the human brain. J Neurochem 3(1):41-51. https://doi. org/10.1111/j.1471-4159.1958.tb12607.x

Halliday GM, Ophof A, Broe M, Jensen PH, Kettle E, Fedorow H, Cartwright MI, Griffiths FM, Shepherd CE, Double KL (2005) $\alpha$-Synuclein redistributes to neuromelanin lipid in the substantia nigra early in Parkinson's disease. Brain 128(11):2654-2664. https://doi.org/10.1093/brain/awh584\%JBrain

Halliwell B (2006) Oxidative stress and neurodegeneration: where are we now? J Neurochem 97(6):1634-1658. https://doi.org/10. 1111/j.1471-4159.2006.03907.x

Hansen AK, Knudsen K, Lillethorup TP, Landau AM, Parbo P, Fedorova T, Audrain H, Bender D, Østergaard K, Brooks DJ, Borghammer P (2016) In vivo imaging of neuromelanin in Parkinson's disease using 18 F-AV-1451 PET. Brain 139(7):2039-2049. https://doi.org/10.1093/brain/aww098\%JBrain

Hare DJ, Double KL (2016) Iron and dopamine: a toxic couple. Brain 139(Pt 4):1026-1035. https://doi.org/10.1093/brain/aww022

Hare DJ, Gerlach M, Riederer P (2012) Considerations for measuring iron in post-mortem tissue of Parkinson's disease patients. J Neural Transm (vienna) 119(12):1515-1521. https://doi.org/10. 1007/s00702-012-0898-4

Harvey K, Outeiro TF (2018) The role of LRRK2 in cell signalling. Biochem Soc Trans 47(1):197-207. https://doi.org/10.1042/ BST20180464

Hauser DN, Primiani CT, Cookson MR (2017) The effects of variants in the Parkin, PINK1, and DJ-1 genes along with evidence for their pathogenicity. Curr Protein Pept Sci 18(7):702-714. https:// doi.org/10.2174/1389203717666160311121954

Henry BM, de Oliveira MHS, Benoit S, Plebani M, Lippi G (2020) Hematologic, biochemical and immune biomarker abnormalities associated with severe illness and mortality in coronavirus disease 2019 (COVID-19): a meta-analysis. Clin Chem Lab Med 58(7):1021-1028. https://doi.org/10.1515/ cclm-2020-0369

Higashi Y, Asanuma M, Miyazaki I, Ogawa N (2000) Inhibition of tyrosinase reduces cell viability in catecholaminergic neuronal cells. J Neurochem 75(4):1771-1774. https://doi.org/10.1046/j. 1471-4159.2000.0751771.x

Hippchen T, Altamura S, Muckenthaler MU, Merle U (2020) Hypoferremia is associated with increased hospitalization and oxygen demand in COVID-19 patients. Hemasphere 4(6):e492. https:// doi.org/10.1097/HS9.0000000000000492

Hirsch EC (1994) Biochemistry of Parkinson's disease with special reference to the dopaminergic systems. Mol Neurobiol 9(1-3):135142. https://doi.org/10.1007/BF02816113

Hirsch EC, Standaert DG (2021) Ten unsolved questions about neuroinflammation in Parkinson's disease. Mov Disord 36(1):16-24. https://doi.org/10.1002/mds.28075

Hirsch E, Graybiel AM, Agid YA (1988) Melanized dopaminergic neurons are differentially susceptible to degeneration in Parkinson's disease. Nature 334(6180):345-348. https://doi.org/10.1038/ $334345 \mathrm{a} 0$

Hirsch EC, Graybiel AM, Agid Y (1989) Selective vulnerability of pigmented dopaminergic neurons in Parkinson's disease. Acta Neurol Scand Suppl 126:19-22. https://doi.org/10.1111/j.16000404.1989.tb01778.x

Hirsch EC, Brandel JP, Galle P, Javoy-Agid F, Agid Y (1991) Iron and aluminum increase in the substantia nigra of patients with Parkinson's disease: an X-ray microanalysis. J Neurochem 56(2):446-451. https://doi.org/10.1111/j.1471-4159.1991.tb081 70.x

Holmqvist S, Chutna O, Bousset L, Aldrin-Kirk P, Li W, Bjorklund T, Wang ZY, Roybon L, Melki R, Li JY (2014) Direct evidence of Parkinson pathology spread from the gastrointestinal tract to the 
brain in rats. Acta Neuropathol 128(6):805-820. https://doi.org/ 10.1007/s00401-014-1343-6

Huang K, Zhao X, Chen X, Gao Y, Yu J, Wu L (2021) Analysis of digestive endoscopic results during COVID-19. J Transl Int Med 9(1):38-42. https://doi.org/10.2478/jtim-2021-0006

Huddleston D, Mahmoudi B, Langley J, Factor S, Crosson B, Hu X (2019) MRI signature of neuromelanin and iron pathology in Parkinson's disease paper presented at the AAN Annual Meeting Science Program, Philadelphia

Iacono D, Geraci-Erck M, Rabin ML, Adler CH, Serrano G, Beach TG, Kurlan R (2015) Parkinson disease and incidental Lewy body disease: just a question of time? Neurology 85(19):1670-1679. https://doi.org/10.1212/wnl.0000000000002102

Ikemoto K, Nagatsu I, Kitahama K, Jouvet A, Nishimura A, Nishi K, Maeda T, Arai R (1998) A dopamine-synthesizing cell group demonstrated in the human basal forebrain by dual labeling immunohistochemical technique of tyrosine hydroxylase and aromatic L-amino acid decarboxylase. Neurosci Lett 243(13):129-132. https://doi.org/10.1016/s0304-3940(98)00103-7

Isaias IU, Trujillo P, Summers P, Marotta G, Mainardi L, Pezzoli G, Zecca L, Costa A (2016) Neuromelanin imaging and dopaminergic loss in Parkinson's disease. Front Aging Neurosci 8:196. https://doi.org/10.3389/fnagi.2016.00196

Jaeggi T, Kortman GA, Moretti D, Chassard C, Holding P, Dostal A, Boekhorst J, Timmerman HM, Swinkels DW, Tjalsma H, Njenga J, Mwangi A, Kvalsvig J, Lacroix C, Zimmermann MB (2015) Iron fortification adversely affects the gut microbiome, increases pathogen abundance and induces intestinal inflammation in Kenyan infants. Gut 64(5):731-742. https://doi.org/10. 1136/gutjnl-2014-307720

Jellinger KA (2014) Neuropathology of Parkinson's disease. In: Thomas M (ed) Inflammation in Parkinson's disease: scientific and clinical aspects. Springer International Publishing, Cham, pp 25-74. https://doi.org/10.1007/978-3-319-08046-8_2

Jellinger KA (2019) Neuropathology and pathogenesis of extrapyramidal movement disorders: a critical update-I. Hypokinetic-rigid movement disorders. J Neural Transm (vienna) 126(8):933-995. https://doi.org/10.1007/s00702-019-02028-6

Jellinger KA, Korczyn AD (2018) Are dementia with Lewy bodies and Parkinson's disease dementia the same disease? BMC Med 16(1):34. https://doi.org/10.1186/s12916-018-1016-8

Jellinger KA, Paulus W (1992) Clinico-pathological correlations in Parkinson's disease. Clin Neurol Neurosurg 94(Suppl):S86-88. https://doi.org/10.1016/0303-8467(92)90033-y

Jellinger K, Paulus W, Grundke-Iqbal I, Riederer P, Youdim MBH (1990) Brain iron and ferritin in Parkinson's and Alzheimer's diseases. J Neural Transm Parkinson's Dis Dementia Sect 2(4):327-340. https://doi.org/10.1007/BF02252926

Jellinger K, Kienzl E, Rumpelmair G, Riederer P, Stachelberger H, Ben-Shachar D, Youdim MB (1992) Iron-melanin complex in substantia nigra of parkinsonian brains: an x-ray microanalysis. J Neurochem 59(3):1168-1171. https://doi.org/10.1111/j.14714159.1992.tb08362.x

Jenner P, Dexter DT, Sian J, Schapira AH, Marsden CD (1992a) Oxidative stress as a cause of nigral cell death in Parkinson's disease and incidental Lewy body disease. The Royal Kings and Queens Parkinson's Disease Research Group. Ann Neurol 32:S82-87. https://doi.org/10.1002/ana.410320714

Jenner P, Schapira AH, Marsden CD (1992b) New insights into the cause of Parkinson's disease. Neurology 42(12):2241-2250. https://doi.org/10.1212/wnl.42.12.2241

Kalia LV, Kalia SK, Chau H, Lozano AM, Hyman BT, McLean PJ (2011) Ubiquitinylation of $\alpha$-synuclein by carboxyl terminus Hsp70-interacting protein (CHIP) is regulated by Bcl-2-associated athanogene 5 (BAG5). PLoS ONE 6(2):e14695. https:// doi.org/10.1371/journal.pone.0014695
Kienzl E, Puchinger L, Jellinger K, Linert W, Stachelberger H, Jameson RF (1995) The role of transition metals in the pathogenesis of Parkinson's disease. J Neurol Sci 134(Suppl):69-78. https:// doi.org/10.1016/0022-510x(95)00210-s

Kishimoto M, Uemura K, Sanaki T, Sato A, Hall WW, Kariwa H, Orba Y, Sawa H, Sasaki M (2021) TMPRSS11D and TMPRSS13 activate the SARS-CoV-2 spike protein. Viruses 13:3. https://doi.org/10.3390/v13030384

Koziorowski D, Friedman A, Arosio P, Santambrogio P, Dziewulska D (2007) ELISA reveals a difference in the structure of substantia nigra ferritin in Parkinson's disease and incidental Lewy body compared to control. Parkinsonism Relat Disord 13(4):214-218. https://doi.org/10.1016/j.parkreldis.2006.10. 002

Kwiatek-Majkusiak J, Geremek M, Koziorowski D, Tomasiuk R, Szlufik S, Friedman A (2020) Serum levels of hepcidin and interleukin 6 in Parkinson's disease. Acta Neurobiol Exp 80(3):297-304

Langley J, He N, Huddleston DE, Chen S, Yan F, Crosson B, Factor S, Hu X (2019) Reproducible detection of nigral iron deposition in 2 Parkinson's disease cohorts. Mov Disord 34(3):416-419. https://doi.org/10.1002/mds.27608

Lashuel HA, Overk CR, Oueslati A, Masliah E (2013) The many faces of alpha-synuclein: from structure and toxicity to therapeutic target. Nat Rev Neurosci 14(1):38-48. https://doi.org/10.1038/ nrn3406

Lee JH, Lee MS (2019) Brain iron accumulation in atypical Parkinsonian syndromes: in vivo MRI evidences for distinctive patterns. Front Neurol 10:74. https://doi.org/10.3389/fneur.2019.00074

Lee H, Baek SY, Kim EJ, Huh GY, Lee JH, Cho H (2020) MRI T2 and $\mathrm{T} 2 *$ relaxometry to visualize neuromelanin in the dorsal substantia nigra pars compacta. Neuroimage 211:116625. https://doi.org/ 10.1016/j.neuroimage.2020.116625

Leveugle B, Faucheux BA, Bouras C, Nillesse N, Spik G, Hirsch EC, Agid Y, Hof PR (1996) Cellular distribution of the iron-binding protein lactotransferrin in the mesencephalon of Parkinson's disease cases. Acta Neuropathol 91(6):566-572. https://doi.org/10. 1007/s004010050468

Lewis PA, Cookson MR (2012) Gene expression in the Parkinson's disease brain. Brain Res Bull 88(4):302-312. https://doi.org/10. 1016/j.brainresbull.2011.11.016

Lhermitte J, Kraus WM, McAlpine D (1924) Original papers: on the occurrence of abnormal deposits of iron in the brain in parkinsonism with special reference to its localisation. J Neurol Psychopathol 5(19): 195-208. https://doi.org/10.1136/jnnp.s1-5.19.195

Liang T, Qian ZM, Mu MD, Yung WH, Ke Y (2020) Brain hepcidin suppresses major pathologies in experimental Parkinsonism. iScience 23(7):101284. https://doi.org/10.1016/j.isci.2020. 101284

Liu X, Chen Z (2017) The pathophysiological role of mitochondrial oxidative stress in lung diseases. J Transl Med 15(1):207. https:// doi.org/10.1186/s12967-017-1306-5

Loeffler DA, Connor JR, Juneau PL, Snyder BS, Kanaley L, DeMaggio AJ, Nguyen H, Brickman CM, LeWitt PA (1995) Transferrin and iron in normal, Alzheimer's disease, and Parkinson's disease brain regions. J Neurochem 65(2):710-724. https://doi.org/10. 1046/j.1471-4159.1995.65020710.x

Ma L, Gholam Azad M, Dharmasivam M, Richardson V, Quinn RJ, Feng Y, Pountney DL, Tonissen KF, Mellick GD, Yanatori I, Richardson DR (2021) Parkinson's disease: alterations in iron and redox biology as a key to unlock therapeutic strategies. Redox Biol 41:101896. https://doi.org/10.1016/j.redox.2021. 101896

Mahat RK, Panda S, Rathore V, Swain S, Yadav L, Sah SP (2021) The dynamics of inflammatory markers in coronavirus disease-2019 (COVID-19) patients: a systematic review and meta-analysis. 
Clin Epidemiol Glob Health 11:100727. https://doi.org/10. 1016/j.cegh.2021.100727

Mandel S, Maor G, Youdim MB (2004) Iron and alpha-synuclein in the substantia nigra of MPTP-treated mice: effect of neuroprotective drugs R-apomorphine and green tea polyphenol (-)-epigallocatechin-3-gallate. J Mol Neurosci 24(3):401-416. https://doi.org/ 10.1385/JMN:24:3:401

Mandel S, Grunblatt E, Riederer P, Amariglio N, Jacob-Hirsch J, Rechavi G, Youdim MB (2005) Gene expression profiling of sporadic Parkinson's disease substantia nigra pars compacta reveals impairment of ubiquitin-proteasome subunits, SKP1A, aldehyde dehydrogenase, and chaperone HSC-70. Ann N Y Acad Sci 1053:356-375. https://doi.org/10.1196/annals.1344.031

Mann DMA, Yates PO (1983) Possible role of neuromelanin in the pathogenesis of Parkinson's disease. Mech Ageing Dev 21(2):193-203. https://doi.org/10.1016/0047-6374(83)90074-X

Marsden CD (1983) Neuromelanin and Parkinson's disease. J Neural Transm Suppl 19:121-141

Martin WR, Wieler M, Gee M (2008) Midbrain iron content in early Parkinson disease: a potential biomarker of disease status. Neurology 70(16 Pt 2):1411-1417. https://doi.org/10.1212/01.wnl. 0000286384.31050.b5

Martin-Bastida A, Pietracupa S, Piccini P (2017) Neuromelanin in parkinsonian disorders: an update. Int J Neurosci 127(12):11161123. https://doi.org/10.1080/00207454.2017.1325883

McGeer PL, Itagaki S, Boyes BE, McGeer EG (1988) Reactive microglia are positive for HLA-DR in the substantia nigra of Parkinson's and Alzheimer's disease brains. Neurology 38(8):12851291. https://doi.org/10.1212/wnl.38.8.1285

Meade RM, Fairlie DP, Mason JM (2019) Alpha-synuclein structure and Parkinson's disease-lessons and emerging principles. Mol Neurodegener 14(1):29. https://doi.org/10.1186/ s13024-019-0329-1

Michel TM, Kasbauer L, Gsell W, Jecel J, Sheldrick AJ, Cortese M, Nickl-Jockschat T, Grunblatt E, Riederer P (2014) Aldehyde dehydrogenase 2 in sporadic Parkinson's disease. Parkinsonism Relat Disord 20(Suppl 1):S68-72. https://doi.org/10.1016/S13538020(13)70018-X

Minotti G, Aust SD (1987) The requirement for iron (III) in the initiation of lipid peroxidation by iron (II) and hydrogen peroxide. J Biol Chem 262(3):1098-1104

Miranda M, Botti D, Bonfigli A, Ventura T, Arcadi A (1984) Tyrosinase-like activity in normal human substantia nigra. Gen Pharmacol 15(6):541-544. https://doi.org/10.1016/0306-3623(84) 90212-x

Mittal S, Wu Z, Neelavalli J, Haacke EM (2009) Susceptibilityweighted imaging: technical aspects and clinical applications, part 2. AJNR Am J Neuroradiol 30(2):232-252. https://doi.org/ 10.3174/ajnr.A1461

Mizuno Y, Ohta S, Tanaka M, Takamiya S, Suzuki K, Sato T, Oya H, Ozawa T, Kagawa Y (1989) Deficiencies in complex I subunits of the respiratory chain in Parkinson's disease. Biochem Biophys Res Commun 163(3):1450-1455. https://doi.org/10.1016/0006$291 \times(89) 91141-8$

Mochizuki H, Choong CJ, Baba K (2020) Parkinson's disease and iron. J Neural Transm (vienna) 127(2):181-187. https://doi.org/10. 1007/s00702-020-02149-3

Mochizuki H (1993) Iron-melanin complex is toxic to dopaminergic neurons in a nigrostriatal co-culture. In: Juntendo University

Mogi M, Harada M, Kondo T, Riederer P, Inagaki H, Minami M, Nagatsu T (1994) Interleukin-1 beta, interleukin-6, epidermal growth factor and transforming growth factor-alpha are elevated in the brain from parkinsonian patients. Neurosci Lett 180(2):147-150. https://doi.org/10.1016/0304-3940(94)90508-8

Morris CM, Candy JM, Omar S, Bloxham CA, Edwardson JA (1994) Transferrin receptors in the parkinsonian midbrain. Neuropathol
Appl Neurobiol 20(5):468-472. https://doi.org/10.1111/j.13652990.1994.tb00997.x

Müller E (1922) Berlinerblau und turnbullsblau. J Praktische Chemie 104(1):241-258. https://doi.org/10.1002/prac.19221040116

Muñoz Y, Carrasco CM, Campos JD, Aguirre P, Núñez MT (2016) Parkinson's disease: the mitochondria-iron link. Parkinsons Dis 2016:7049108. https://doi.org/10.1155/2016/7049108

Murer MG, Dziewczapolski G, Menalled LB, Garcia MC, Agid Y, Gershanik O, Raisman-Vozari R (1998) Chronic levodopa is not toxic for remaining dopamine neurons, but instead promotes their recovery, in rats with moderate nigrostriatal lesions. Ann Neurol 43(5):561-575. https://doi.org/10.1002/ana.410430504

Nai A, Lore NI, Pagani A, De Lorenzo R, Di Modica S, Saliu F, Cirillo DM, Rovere-Querini P, Manfredi AA, Silvestri L (2021) Hepcidin levels predict COVID-19 severity and mortality in a cohort of hospitalized Italian patients. Am J Hematol 96(1):E32-E35. https://doi.org/10.1002/ajh.26027

Nemeth E, Ganz T (2009) The role of hepcidin in iron metabolism. Acta Haematol 122(2-3):78-86. https://doi.org/10.1159/00024 3791

Oestreicher E, Sengstock GJ, Riederer P, Olanow CW, Dunn AJ, Arendash GW (1994) Degeneration of nigrostriatal dopaminergic neurons increases iron within the substantia nigra: a histochemical and neurochemical study. Brain Res 660(1):8-18. https://doi.org/ 10.1016/0006-8993(94)90833-8

Okun MR (1997) The role of peroxidase in neuromelanin synthesis: a review. Physiol Chem Phys Med NMR 29(1):15-22

Pan T, Zhu J, Hwu WJ, Jankovic J (2012) The role of alpha-synuclein in melanin synthesis in melanoma and dopaminergic neuronal cells. PLoS ONE 7(9):e45183. https://doi.org/10.1371/journal. pone. 0045183

Park JH, Burgess JD, Faroqi AH, DeMeo NN, Fiesel FC, Springer W, Delenclos M, McLean PJ (2020) Alpha-synuclein-induced mitochondrial dysfunction is mediated via a sirtuin 3-dependent pathway. Mol Neurodegener 15(1):5. https://doi.org/10.1186/ s13024-019-0349-x

Pavese N, Tai YF (2018) Nigrosome imaging and neuromelanin sensitive MRI in diagnostic evaluation of parkinsonism. Mov Disord Clin Pract 5(2):131-140. https://doi.org/10.1002/mdc3.12590

Pearce RK, Owen A, Daniel S, Jenner P, Marsden CD (1997) Alterations in the distribution of glutathione in the substantia nigra in Parkinson's disease. J Neural Transm (vienna) 104(6-7):661677. https://doi.org/10.1007/BF01291884

Peelaerts W, Bousset L, Baekelandt V, Melki R (2018) a-Synuclein strains and seeding in Parkinson's disease, incidental Lewy body disease, dementia with Lewy bodies and multiple system atrophy: similarities and differences. Cell Tissue Res 373(1):195212. https://doi.org/10.1007/s00441-018-2839-5

Perez-Pardo P, Kliest T, Dodiya HB, Broersen LM, Garssen J, Keshavarzian A, Kraneveld AD (2017) The gut-brain axis in Parkinson's disease: possibilities for food-based therapies. Eur J Pharmacol 817:86-95. https://doi.org/10.1016/j.ejphar.2017.05.042

Perfeito R, Ribeiro M, Rego AC (2017) Alpha-synuclein-induced oxidative stress correlates with altered superoxide dismutase and glutathione synthesis in human neuroblastoma SH-SY5Y cells. Arch Toxicol 91(3):1245-1259. https://doi.org/10.1007/ s00204-016-1788-6

Perrett RM, Alexopoulou Z, Tofaris GK (2015) The endosomal pathway in Parkinson's disease. Mol Cell Neurosci 66(Pt A):21-28. https://doi.org/10.1016/j.mcn.2015.02.009

Plum S, Steinbach S, Attems J, Keers S, Riederer P, Gerlach M, May C, Marcus K (2016) Proteomic characterization of neuromelanin granules isolated from human substantia nigra by laser-microdissection. Sci Rep 6(1):37139. https://doi.org/10.1038/srep37139

Priovoulos N, van Boxel SCJ, Jacobs HIL, Poser BA, Uludag K, Verhey FRJ, Ivanov D (2020) Unraveling the contributions to the 
neuromelanin-MRI contrast. Brain Struct Funct 225(9):27572774. https://doi.org/10.1007/s00429-020-02153-z

Pyatigorskaya N, Sanz-Morere CB, Gaurav R, Biondetti E, Valabregue R, Santin M, Yahia-Cherif L, Lehericy S (2020) Iron imaging as a diagnostic tool for Parkinson's disease: a systematic review and meta-analysis. Front Neurol 11:366. https://doi.org/10.3389/ fneur.2020.00366

Qian ZM, Wang Q (1998) Expression of iron transport proteins and excessive iron accumulation in the brain in neurodegenerative disorders. Brain Res Rev 27(3):257-267. https://doi.org/10.1016/ S0165-0173(98)00012-5

Ramsay AJ, Hooper JD, Folgueras AR, Velasco G, López-Otín C (2009) Matriptase-2 (TMPRSS6): a proteolytic regulator of iron homeostasis. Haematologica 94(6):840-849. https://doi.org/10. 3324/haematol.2008.001867

Rausch WD, Hirata Y, Nagatsu T, Riederer P, Jellinger K (1988) Tyrosine hydroxylase activity in caudate nucleus from Parkinson's disease: effects of iron and phosphorylating agents. J Neurochem 50(1):202-208. https://doi.org/10.1111/j.1471-4159.1988.tb132 50. $\mathrm{x}$

Recasens A, Dehay B, Bove J, Carballo-Carbajal I, Dovero S, PerezVillalba A, Fernagut PO, Blesa J, Parent A, Perier C, Farinas I, Obeso JA, Bezard E, Vila M (2014) Lewy body extracts from Parkinson disease brains trigger alpha-synuclein pathology and neurodegeneration in mice and monkeys. Ann Neurol 75(3):351362. https://doi.org/10.1002/ana.24066

Reichmann H, Riederer P (1989) Biochemische Analyse der Atmungskettenkomplexe verschiedener Hirnregionen von Patienten mit Morbus Parkinson. In: Oertel H (ed) Morbus Parkinson und andere Basalganglienerkrankungen. BMFT Symposium Bad Kissingen, $\mathrm{p} 44$

Richardson DR, Lane DJ, Becker EM, Huang ML, Whitnall M, Suryo Rahmanto Y, Sheftel AD, Ponka P (2010) Mitochondrial iron trafficking and the integration of iron metabolism between the mitochondrion and cytosol. Proc Natl Acad Sci USA 107(24):10775-10782. https://doi.org/10.1073/pnas. 0912925107

Riederer PF (2004) Views on neurodegeneration as a basis for neuroprotective strategies. Med Sci Monitor 10:12

Riederer P, Meulen V (2020) Coronaviruses: a challenge of today and a call for extended human postmortem brain analyses. $\mathrm{J}$ Neural Transm. https://doi.org/10.1007/s00702-020-02230-X

Riederer P, Rausch WD, Schmidt B, Kruzik P, Konradi C, Sofić E, Danielczyk W, Fischer M, Ogris E (1988) Biochemical fundamentals of Parkinson's disease. Mt Sinai J Med 55(1):21-28

Riederer P, Sofic E, Rausch WD, Schmidt B, Reynolds GP, Jellinger K, Youdim MB (1989) Transition metals, ferritin, glutathione, and ascorbic acid in parkinsonian brains. J Neurochem 52(2):515-520. https://doi.org/10.1111/j.1471-4159. 1989.tb09150.x

Riederer P, Dirr A, Goetz M, Sofic E, Jellinger K, Youdim MB (1992) Distribution of iron in different brain regions and subcellular compartments in Parkinson's disease. Ann Neurol 32(Suppl):S101-104. https://doi.org/10.1002/ana.410320717

Riederer P, Berg D, Casadei N, Cheng F, Classen J, Dresel C, Jost W, Kruger R, Muller T, Reichmann H, Riess O, Storch A, Strobel S, van Eimeren T, Volker HU, Winkler J, Winklhofer KF, Wullner U, Zunke F, Monoranu CM (2019) Alpha-synuclein in Parkinson's disease: causal or bystander? J Neural Transm (vienna) 126(7):815-840. https://doi.org/10.1007/s00702-019-02025-9

Riederer P, Sofič E, Rausch WD, Kruzik P, Youdim MBH (1985) Dopaminforschung heute und morgen-L-Dopa in der Zukunft. In: Riederer P, Umek H (eds) L-Dopa-Substitution der Parkinson-Krankheit: Geschichte-Gegenwart-Zukunft. Springer, Vienna, pp 127-144. https://doi.org/10.1007/978-3-7091-88224_14
Rossi M, Ruottinen H, Soimakallio S, Elovaara I, Dastidar P (2013) Clinical MRI for iron detection in Parkinson's disease. Clin Imaging 37(4):631-636. https://doi.org/10.1016/j.clinimag. 2013.02.001

Rutledge JN, Hilal SK, Silver AJ, Defendini R, Fahn S (1987) Study of movement disorders and brain iron by MR. AJR Am J Roentgenol 149(2):365-379. https://doi.org/10.2214/ajr.149.2.365

Ryvlin P, Broussolle E, Piollet H, Viallet F, Khalfallah Y, Chazot G (1995) Magnetic resonance imaging evidence of decreased putamenal iron content in idiopathic Parkinson's disease. Arch Neurol 52(6):583-588. https://doi.org/10.1001/archneur.1995. 00540300057013

Saggu H, Cooksey J, Dexter D, Wells FR, Lees A, Jenner P, Marsden CD (1989) A selective increase in particulate superoxide dismutase activity in parkinsonian substantia nigra. J Neurochem 53(3):692-697. https://doi.org/10.1111/j.1471-4159.1989.tb117 59. $\mathrm{x}$

Sammarco MC, Ditch S, Banerjee A, Grabczyk E (2008) Ferritin L and $\mathrm{H}$ subunits are differentially regulated on a post-transcriptional level*. J Biol Chem 283(8):4578-4587. https://doi.org/10.1074/ jbc.M703456200

Schapira AH, Cooper JM, Dexter D, Jenner P, Clark JB, Marsden CD (1989) Mitochondrial complex I deficiency in Parkinson's disease. Lancet 1(8649):1269. https://doi.org/10.1016/s01406736(89)92366-0

Schapira AH, Cooper JM, Dexter D, Clark JB, Jenner P, Marsden CD (1990) Mitochondrial complex I deficiency in Parkinson's disease. J Neurochem 54(3):823-827. https://doi.org/10.1111/j. 1471-4159.1990.tb02325.x

Schmidt M (1940) Störungen des eisenstoffwechsels und ihre folgen. Ergebn Allg Path Path Anat 35:105-208

Schmidt SM (2020) The role of iron in viral infections. Front Biosci (landmark Ed) 25:893-911

Schneider SA (2016) Neurodegeneration with brain iron accumulation. Curr Neurol Neurosci Rep 16(1):9. https://doi.org/10.1007/ s11910-015-0608-3

Schrag M, Dickson A, Jiffry A, Kirsch D, Vinters HV, Kirsch W (2010) The effect of formalin fixation on the levels of brain transition metals in archived samples. Biometals 23(6):1123-1127. https:// doi.org/10.1007/s10534-010-9359-4

Seitelberger F (1964) Viral encephalitis and the autonomic nervous system. Acta Neuroveg (wien) 26:494-509. https://doi.org/10. 1007/BF01252145

Sengstock GJ, Olanow CW, Dunn AJ, Arendash GW (1992) Iron induces degeneration of nigrostriatal neurons. Brain Res Bull 28(4):645-649. https://doi.org/10.1016/0361-9230(92)90118-h

Shamoto-Nagai M, Maruyama W, Yi H, Akao Y, Tribl F, Gerlach M, Osawa T, Riederer P, Naoi M (2006) Neuromelanin induces oxidative stress in mitochondria through release of iron: mechanism behind the inhibition of $26 \mathrm{~S}$ proteasome. J Neural Transm (vienna) 113(5):633-644. https://doi.org/10.1007/ s00702-005-0410-5

Sherer TB, Betarbet R, Kim JH, Greenamyre JT (2003) Selective microglial activation in the rat rotenone model of Parkinson's disease. Neurosci Lett 341(2):87-90. https://doi.org/10.1016/ s0304-3940(03)00172-1

Shin WH, Park JH, Chung KC (2020) The central regulator p62 between ubiquitin proteasome system and autophagy and its role in the mitophagy and Parkinson's disease. BMB Rep 53(1):56-63

Sian J, Dexter DT, Lees AJ, Daniel S, Jenner P, Marsden CD (1994) Glutathione-related enzymes in brain in Parkinson's disease. Ann Neurol 36(3):356-361. https://doi.org/10.1002/ana.410360306

Sian J, Dexter DT, Jenner P et al (1991) Decrease in nigral reduced glutathione in Parkinson's Disease. Brit J Pharmacol (Dec., London meeting) 
Sian-Hulsmann J, Riederer P (2020) The role of alpha-synuclein as ferrireductase in neurodegeneration associated with Parkinson's disease. J Neural Transm 127(5):749-754. https://doi.org/10. 1007/s00702-020-02192-0

Sian-Hulsmann J, Riederer P (2021) The Nigral coup in Parkinson's disease by $\alpha$-synuclein and its associated rebels. Cells 10(3):598

Sian-Hulsmann J, Mandel S, Youdim MB, Riederer P (2011) The relevance of iron in the pathogenesis of Parkinson's disease. J Neurochem 118(6):939-957. https://doi.org/10.1111/j.14714159.2010.07132.x

Sian-Hulsmann J, Monoranu C, Strobel S, Riederer P (2015) Lewy bodies: a spectator or salient killer? CNS Neurol Disord Drug Targets 14(7):947-955. https://doi.org/10.2174/1871527314 666150317225659

Sigel A, Sigel B, Sigel KO (2006) Metal ions in life sciences vol I. Neurodegenerative diseases and metal ions

Smeyne M, Smeyne RJ (2013) Glutathione metabolism and Parkinson's disease. Free Radic Biol Med 62:13-25. https://doi.org/ 10.1016/j.freeradbiomed.2013.05.001

Sofic E, Riederer P, Heinsen H, Beckmann H, Reynolds GP, Hebenstreit G, Youdim MB (1988) Increased iron (III) and total iron content in post-mortem substantia nigra of parkinsonian brain. J Neural Transm 74(3):199-205. https://doi.org/10.1007/BF012 44786

Sofic E, Paulus W, Jellinger K, Riederer P, Youdim MB (1991) Selective increase of iron in substantia nigra zona compacta of parkinsonian brains. J Neurochem 56(3):978-982. https://doi.org/ 10.1111/j.1471-4159.1991.tb02017.x

Sofic E, Lange KW, Jellinger K, Riederer P (1992) Reduced and oxidized glutathione in the substantia nigra of patients with Parkinson's disease. Neurosci Lett 142(2):128-130. https://doi.org/10. 1016/0304-3940(92)90355-b

Sonnweber T, Boehm A, Sahanic S, Pizzini A, Aichner M, Sonnweber B, Kurz K, Koppelstatter S, Haschka D, Petzer V, Hilbe R, Theurl M, Lehner D, Nairz M, Puchner B, Luger A, Schwabl C, Bellmann-Weiler R, Woll E, Widmann G, Tancevski I, Judith Loffler R, Weiss G (2020) Persisting alterations of iron homeostasis in COVID-19 are associated with non-resolving lung pathologies and poor patients' performance: a prospective observational cohort study. Respir Res 21(1):276. https://doi. org/10.1186/s12931-020-01546-2

Spatz H (1922) Über den eisennachweis im gehirn, besonders in zentren des extrapyramidal-motorischen systems. I. Teil. Zeitschr Die Gesamte Neurol Psychiatrie 77(1):261-390. https://doi. org/10.1007/BF02865844

Stern P, Kadžović S, Nikolin B (1967) Bedeutung des Eisens im Corpus striatum für den Tremor. Naunyn Schmiedebergs Arch Pharmakol Exp Pathol 257(1):67-68. https://doi.org/10.1007/ BF00537443

Stockwell BR, Friedmann Angeli JP, Bayir H, Bush AI, Conrad M, Dixon SJ, Fulda S, Gascón S, Hatzios SK, Kagan VE, Noel K, Jiang X, Linkermann A, Murphy ME, Overholtzer M, Oyagi A, Pagnussat GC, Park J, Ran Q, Rosenfeld CS, Salnikow K, Tang D, Torti FM, Torti SV, Toyokuni S, Woerpel KA, Zhang DD (2017) Ferroptosis: a regulated cell death nexus linking metabolism, redox biology, and disease. Cell 171(2):273-285. https://doi.org/10.1016/j.cell.2017.09.021

Sulzer D, Edwards RH (2019) The physiological role of $\alpha$-synuclein and its relationship to Parkinson's Disease. J Neurochem 150(5):475-486. https://doi.org/10.1111/jnc.14810

Sulzer D, Bogulavsky J, Larsen KE, Behr G, Karatekin E, Kleinman MH, Turro N, Krantz D, Edwards RH, Greene LA, Zecca L (2000) Neuromelanin biosynthesis is driven by excess cytosolic catecholamines not accumulated by synaptic vesicles. Proc Natl Acad Sci USA 97(22):11869-11874. https://doi.org/ 10.1073/pnas.97.22.11869
Tapias V (2019) Editorial: mitochondrial dysfunction and neurodegeneration. Front Neurosci 13:1372. https://doi.org/10.3389/ fnins.2019.01372

Temlett JA, Landsberg JP, Watt F, Orime GW (1994) Increased iron in the substantia nigra compacta of the MPTP-lesioned hemiparkinsonian African green monkey: evidence from proton microprobe elemental microanalysis. J Neurochem 62(1):134146. https://doi.org/10.1046/j.1471-4159.1994.62010134.x

Tief K, Schmidt A, Beermann F (1998) New evidence for presence of tyrosinase in substantia nigra, forebrain and midbrain. Brain Res Mol Brain Res 53(1-2):307-310. https://doi.org/10.1016/ s0169-328x(97)00301-x

Tong J, Rathitharan G, Meyer JH, Furukawa Y, Ang LC, Boileau I, Guttman M, Hornykiewicz O, Kish SJ (2017) Brain monoamine oxidase $\mathrm{B}$ and $\mathrm{A}$ in human parkinsonian dopamine deficiency disorders. Brain 140(9):2460-2474. https://doi.org/10. 1093/brain/awx172

Torlasco C, Cassinerio E, Roghi A, Faini A, Capecchi M, AbdelGadir A, Giannattasio C, Parati G, Moon JC, Cappellini MD, Pedrotti P (2018) Role of T1 mapping as a complementary tool to $\mathrm{T} 2 *$ for non-invasive cardiac iron overload assessment. PLoS ONE 13(2):e0192890. https://doi.org/10.1371/journal. pone. 0192890

Tribl F, Gerlach M, Marcus K, Asan E, Tatschner T, Arzberger T, Meyer HE, Bringmann G, Riederer P (2005) "Subcellular proteomics" of neuromelanin granules isolated from the human brain. Mol Cell Proteomics 4(7):945-957. https://doi.org/10. 1074/mcp.M400117-MCP200

Tribl F, Marcus K, Meyer HE, Bringmann G, Gerlach M, Riederer P (2006) Subcellular proteomics reveals neuromelanin granules to be a lysosome-related organelle. J Neural Transm (vienna) 113(6):741-749. https://doi.org/10.1007/s00702-006-0452-3

Tribl F, Arzberger T, Riederer P, Gerlach M (2007) Tyrosinase is not detected in human catecholaminergic neurons by immunohistochemistry and Western blot analysis. J Neural Transm Suppl 72:51-55. https://doi.org/10.1007/978-3-211-73574-9_8

Tribl F, Asan E, Arzberger T, Tatschner T, Langenfeld E, Meyer HE, Bringmann G, Riederer P, Gerlach M, Marcus K (2009) Identification of L-ferritin in neuromelanin granules of the human substantia nigra: a targeted proteomics approach. Mol Cell Proteomics 8(8):1832-1838. https://doi.org/10.1074/mcp.M9000 06-MCP200

Trist BG, Hare DJ, Double KL (2019) Oxidative stress in the aging substantia nigra and the etiology of Parkinson's disease. Aging Cell 18(6):e13031. https://doi.org/10.1111/acel.13031

Uitti RJ, Rajput AH, Rozdilsky B, Bickis M, Wollin T, Yuen WK (1989) Regional metal concentrations in Parkinson's disease, other chronic neurological diseases, and control brains. Can J Neurol Sci 16(3):310-314. https://doi.org/10.1017/s031716710 0029140

Ule G, Volkl A, Berlet H (1974) Trace elements in human brain. II Copper, zinc, calcium and magnesium of 13 brain areas compared to iron during the 4th to 8th life decade (author's transl). Z Neurol 206(2):117-128

Urban P, Falkenburger B, Jost WH, Ransmayr G, Riederer P, Winkler C (2020) Struktur und efferenzen der substantia nigra pars compacta beim idiopathischen Parkinson-Syndrom (structure and efferences of the substantia nigra pars compacta in Parkinson's disease). Fortschr Neurol Psychiatr 88(09):591-599

Varanita T, Bubacco L (2020) Chapter 27 - Alpha-synuclein and neuroinflammation in Parkinson's disease. In: Martin CR, Preedy VR (eds) Genetics, neurology, behavior, and diet in Parkinson's disease. Academic Press, Cambridge, pp 431-446. https://doi. org/10.1016/B978-0-12-815950-7.00027-8 
Vela D (2018) The dual role of hepcidin in brain iron load and inflammation. Front Neurosci 12:740. https://doi.org/10.3389/fnins. 2018.00740

Vetter P, Vu DL, L'Huillier AG, Schibler M, Kaiser L, Jacquerioz F (2020) Clinical features of covid-19. BMJ 369:m1470. https:// doi.org/10.1136/bmj.m1470

Vila M (2019) Neuromelanin, aging, and neuronal vulnerability in Parkinson's disease. Mov Disord 34(10):1440-1451. https://doi.org/ 10.1002/mds. 27776

Vila M, Laguna A, Carballo-Carbajal I (2019) Intracellular crowding by age-dependent neuromelanin accumulation disrupts neuronal proteostasis and triggers Parkinson disease pathology. Autophagy 15(11):2028-2030. https://doi.org/10.1080/15548627.2019. 1659621

Villapol S (2020) Gastrointestinal symptoms associated with COVID19: impact on the gut microbiome. Transl Res 226:57-69. https:// doi.org/10.1016/j.trsl.2020.08.004

Visanji NP, Collingwood JF, Finnegan ME, Tandon A, House E, Hazrati LN (2013) Iron deficiency in parkinsonism: region-specific iron dysregulation in Parkinson's disease and multiple system atrophy. J Parkinsons Dis 3(4):523-537. https://doi.org/10.3233/ JPD-130197

Volkl A, Ule G (1972) Trace elements in human brain. Iron concentration of 13 brain areas as a function of age. Z Neurol 202(4):331-338

Wang JY, Zhuang QQ, Zhu LB, Zhu H, Li T, Li R, Chen SF, Huang CP, Zhang X, Zhu JH (2016) Meta-analysis of brain iron levels of Parkinson's disease patients determined by postmortem and MRI measurements. Sci Rep 6:36669. https://doi.org/10.1038/ srep36669

Ward RJ, Crichton RR (2019) Ironing out the brain. Met Ions Life Sci. https://doi.org/10.1515/9783110527872-010

Weng J, Li Y, Li J, Shen L, Zhu L, Liang Y, Lin X, Jiao N, Cheng S, Huang Y, Zou Y, Yan G, Zhu R, Lan P (2021) Gastrointestinal sequelae 90 days after discharge for COVID-19. Lancet Gastroenterol Hepatol 6(5):344-346. https://doi.org/10.1016/S24681253(21)00076-5

Wesemann W, Blaschke S, Solbach M, Grote C, Clement HW, Riederer $P$ (1994) Intranigral injected iron progressively reduces striatal dopamine metabolism. J Neural Transm Park Dis Dement Sect 8(3):209-214. https://doi.org/10.1007/BF02260941

Wong YC, Krainc D (2017) $\alpha$-synuclein toxicity in neurodegeneration: mechanism and therapeutic strategies. Nat Med 23(2):1-13. https://doi.org/10.1038/nm.4269

Wu F, Xu HD, Guan JJ, Hou YS, Gu JH, Zhen XC, Qin ZH (2015) Rotenone impairs autophagic flux and lysosomal functions in Parkinson's disease. Neuroscience 284:900-911. https://doi.org/ 10.1016/j.neuroscience.2014.11.004

Wypijewska A, Galazka-Friedman J, Bauminger ER, Wszolek ZK, Schweitzer KJ, Dickson DW, Jaklewicz A, Elbaum D, Friedman A (2010) Iron and reactive oxygen species activity in parkinsonian substantia nigra. Parkinsonism Relat Disord 16(5):329-333. https://doi.org/10.1016/j.parkreldis.2010.02.007

Xiang L, Lou Y, Liu L, Liu Y, Zhang W, Deng J, Guan Y, She M, You X, Liu M, Li H, Xu X, Liu F, Cai X (2020) Gut microbiotic features aiding the diagnosis of acute ischemic stroke. Front Cell Infect Microbiol 10:587284. https://doi.org/10.3389/fcimb.2020. 587284

Xu Y, Stokes AH, Freeman WM, Kumer SC, Vogt BA, Vrana KE (1997) Tyrosinase mRNA is expressed in human substantia nigra. Brain Res Mol Brain Res 45(1):159-162. https://doi.org/10.1016/ s0169-328x(96)00308-7

Xu X, Wang Q, Zhang M (2008) Age, gender, and hemispheric differences in iron deposition in the human brain: an in vivo MRI study. Neuroimage 40(1):35-42. https://doi.org/10.1016/j.neuro image.2007.11.017
Xuan Q, Xu SL, Lu DH, Yu S, Zhou M, Ueda K, Cui YQ, Zhang BY, Chan P (2011) Increased expression of alpha-synuclein in aged human brain associated with neuromelanin accumulation. $\mathbf{J}$ Neural Transm (vienna) 118(11):1575-1583. https://doi.org/10. 1007/s00702-011-0636-3

Yan N, Zhang J (2020) Iron metabolism, ferroptosis, and the links with Alzheimer's disease. Front Neurosci 13:1443. https://doi.org/10. 3389/fnins.2019.01443

Yilmaz B, Li H (2018) Gut microbiota and iron: the crucial actors in health and disease. Pharmaceuticals (basel) 11:4. https://doi.org/ 10.3390/ph11040098

Youdim MBH, Ben-Shachar D, Riederer P (1989) Is Parkinson's disease a progressive siderosis of substantia nigra resulting in iron and melanin induced neurodegeneration? Acta Neurol Scand 80(126):47-54. https://doi.org/10.1111/j.1600-0404.1989.tb017 82. $\mathrm{x}$

Youdim MB, Ben-Shachar D, Riederer P (1990) The role of monoamine oxidase, iron-melanin interaction, and intracellular calcium in Parkinson's disease. J Neural Transm Suppl 32:239-248. https:// doi.org/10.1007/978-3-7091-9113-2_34

Youdim MB, Ben-Shachar D, Eshel G, Finberg JP, Riederer P (1993) The neurotoxicity of iron and nitric oxide. Relevance to the etiology of Parkinson's disease. Adv Neurol 60:259-266

Young KL, Kassouf C, Dolinska MB, Anderson DE, Sergeev YV (2020) Human tyrosinase: temperature-dependent kinetics of oxidase activity. Int J Mol Sci 21:3. https://doi.org/10.3390/ ijms 21030895

Zatloukal K, Stumptner C, Fuchsbichler A, Heid H, Schnoelzer M, Kenner L, Kleinert R, Prinz M, Aguzzi A, Denk H (2002) p62 Is a common component of cytoplasmic inclusions in protein aggregation diseases. Am J Pathol 160(1):255-263. https://doi. org/10.1016/S0002-9440(10)64369-6

Zecca L, Gallorini M, Schunemann V, Trautwein AX, Gerlach M, Riederer P, Vezzoni P, Tampellini D (2001) Iron, neuromelanin and ferritin content in the substantia nigra of normal subjects at different ages: consequences for iron storage and neurodegenerative processes. J Neurochem 76(6):1766-1773. https://doi.org/10. 1046/j.1471-4159.2001.00186.x

Zecca L, Stroppolo A, Gatti A, Tampellini D, Toscani M, Gallorini M, Giaveri G, Arosio P, Santambrogio P, Fariello RG, Karatekin E, Kleinman MH, Turro N, Hornykiewicz O, Zucca FA (2004a) The role of iron and copper molecules in the neuronal vulnerability of locus coeruleus and substantia nigra during aging. Proc Natl Acad Sci USA 101(26):9843-9848. https://doi.org/10.1073/pnas. 0403495101

Zecca L, Youdim MBH, Riederer P, Connor JR, Crichton RR (2004b) Iron, brain ageing and neurodegenerative disorders. Nat Rev Neurosci 5(11):863-873. https://doi.org/10.1038/nrn1537

Zecca L, Casella L, Albertini A, Bellei C, Zucca FA, Engelen M, Zadlo A, Szewczyk G, Zareba M, Sarna T (2008) Neuromelanin can protect against iron-mediated oxidative damage in system modeling iron overload of brain aging and Parkinson's disease. J Neurochem 106(4):1866-1875. https://doi.org/10.1111/j.14714159.2008.05541.x

Zhu Y, Wang B, Tao K, Yang H, Wang Y, Zhou T, Yang Y, Yuan L, Liu X, Duan Y (2017) Iron accumulation and microglia activation contribute to substantia nigra hyperechogenicity in the 6-OHDA-induced rat model of Parkinson's disease. Parkinsonism Relat Disord 36:76-82. https://doi.org/10.1016/j.parkreldis. 2017.01.003

Zucca FA, Segura-Aguilar J, Ferrari E, Munoz P, Paris I, Sulzer D, Sarna T, Casella L, Zecca L (2017) Interactions of iron, dopamine and neuromelanin pathways in brain aging and Parkinson's disease. Prog Neurobiol 155:96-119. https://doi.org/10.1016/j. pneurobio.2015.09.012 
Zucca FA, Vanna R, Cupaioli FA, Bellei C, De Palma A, Di Silvestre D, Mauri P, Grassi S, Prinetti A, Casella L, Sulzer D, Zecca L (2018) Neuromelanin organelles are specialized autolysosomes that accumulate undegraded proteins and lipids in aging human brain and are likely involved in Parkinson's disease. Npj Parkinson's Dis 4(1):17. https://doi.org/10.1038/s41531-018-0050-8
Zupan G, Šuput D, Pirtošek Z, Vovk A (2019) Semi-Automatic signature-based segmentation method for quantification of neuromelanin in substantia nigra. Brain Sci 9(12):335

Publisher's Note Springer Nature remains neutral with regard to jurisdictional claims in published maps and institutional affiliations.

\section{Authors and Affiliations}

\section{P. Riederer ${ }^{1,2} \cdot$ C. Monoranu ${ }^{3} \cdot$ S. Strobel ${ }^{3} \cdot$ T. Iordache $^{4} \cdot$ J. Sian-Hülsmann ${ }^{5}$}

\section{P. Riederer}

jntspringer@web.de

1 Clinic and Policlinic for Psychiatry, Psychosomatics and Psychotherapy, University Hospital Wuerzburg, University of Wuerzburg, Wuerzburg, Germany

2 Department of Psychiatry, University of Southern Denmark, Odense, Denmark
3 Institute of Pathology, Department of Neuropathology, University of Wuerzburg, Wuerzburg, Germany

4 George Emil Palade University of Medicine, Pharmacy, Science and Technology of Targu Mures, Târgu Mureş, Romania

5 Department of Medical Physiology, University of Nairobi, P.O. Box 30197, Nairobi 00100, Kenya 